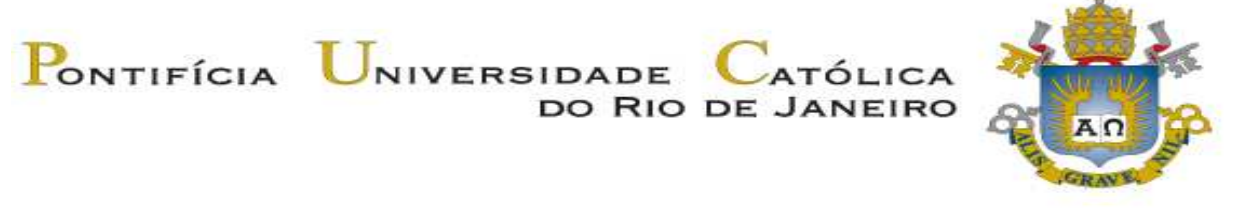

Pós-Graduação Lato Sensu em Língua Inglesa

ALINE FÁTIMA PEREIRA DA COSTA SOUZA

\title{
CANONICAL OR GRAPHIC NOVELS IN AN ENGLISH LANGUAGE CLASSROOM: STUDENTS' REACTIONS
}

\author{
Rio de Janeiro
}

Dezembro de 2017 
Pontifícia Universidade Católica DO RIO DE JANEIRO

ALINE FÁTIMA PEREIRA DA COSTA SOUZA

CANONICAL OR GRAPHIC NOVELS IN AN ENGLISH LANGUAGE CLASSROOM: STUDENTS' REACTIONS

Monografia apresentada ao programa de Pós-graduação em Letras da PUC-Rio como requisito parcial para obtenção do título de especialista em Língua Inglesa.

Orientadoras:

Prof ${ }^{a}$ Juliana Jandre

Prof ${ }^{a}$ Sonia Zyngier

Rio de Janeiro

Dezembro de 2017 


\section{Acknowledgements}

I would like to express my special thanks to my advisors Dr. Juliana Jandre and Dr. Sonia Zyngier, who not only helped me but also showed a world of possibilities with this work.

I would also like to thank Isadora Guise, for giving me the opportunity to develop this work in our school, as well as Yule Souza, Carol Lavor and Isabela Queiroz, the efficient librarians who helped me throughout this work. My thanks also go to my best friends Renata Velloso and Karen Dias, who helped me from the very beginning of this course.

I would also like to thank PUC-Rio for the excellent course offered. At last and most importantly, I would like to dedicate this paper to my parents, who were always there for me. 
"And what is the use of a book," thought Alice, "without pictures or conversation?"

Lewis Carrol, Alice' Adventures in

Wonderland 
Souza, Aline Fátima Pereira da Costa; Jandre, Juliana. (Advisor). Zyngier, Sonia (Advisor). Canonical or Graphic Novels in an English language classroom: students' reactions. Rio de Janeiro, 2017, 86 p. Monograph - Departamento de Letras, Pontifícia Universidade Católica do Rio de Janeiro.

\section{ABSTRACT}

Graphic novels can be considered an interesting resource to be used in English language classrooms due to the fact that the illustrations they provide may help students understand the text more easily (CRAWFORD, 2004). In addition, as they present less text, they may be considered to be a more encouraging reading option for students (KRASHEN, 1993). In order to check whether these assumptions are correct and whether students enjoy the graphic novel reading experience, this study compares students' reactions to the reading of the same story in the format of a graphic novel and of a canonical book. This research was carried out with sixty 4th grade students in a private bilingual school in Rio de Janeiro. Students were asked to read the text and then answer a questionnaire about the way they felt while reading the text and the way they evaluated the text itself. Results showed that students liked both types of text and there were no significant differences in their reading reactions. The results indicate that students appreciate graphic novels. However, it should not be considered as the key to solve students' reading issues. Graphic novels should be used as a bridge but not as a replacement for canonical books.

Keywords: graphic novel, reader response theory, foregrounding, readers, feelings 


\section{TABLE OF CONTENTS}

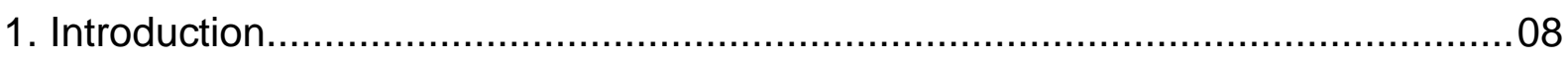

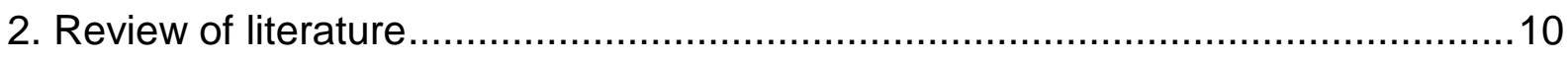

2.1 Graphic novel

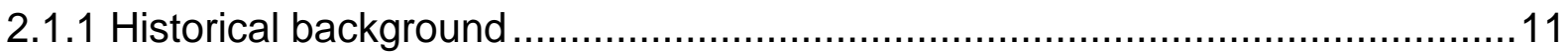

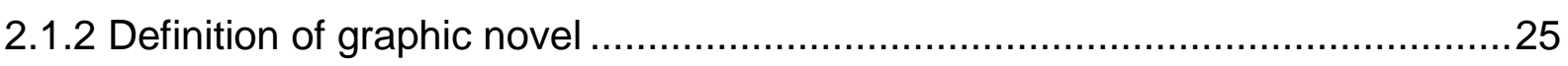

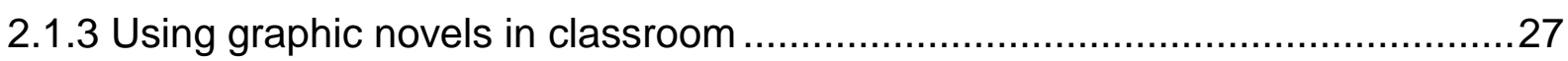

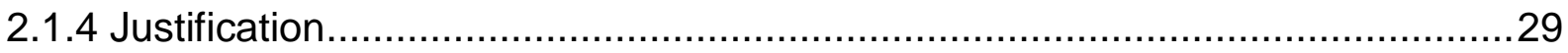

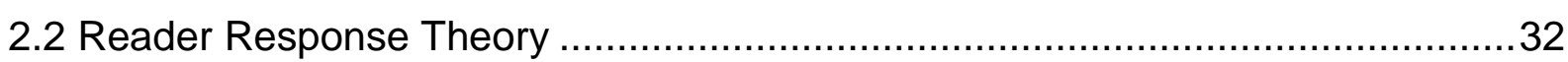

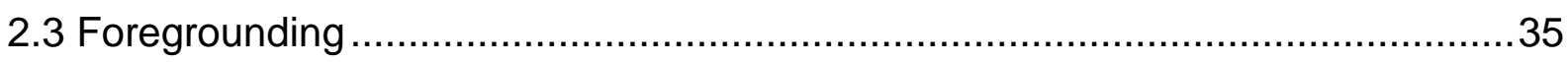

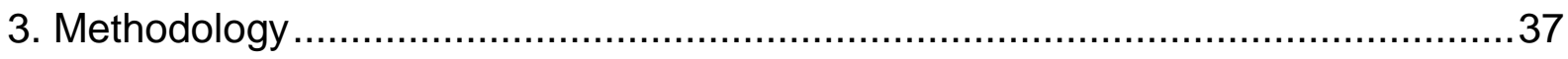

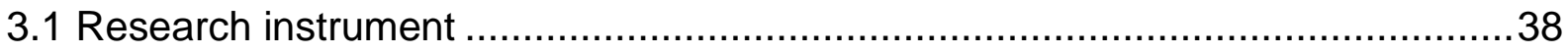

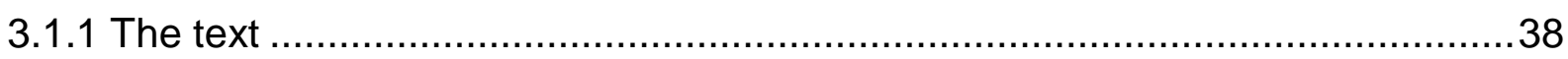

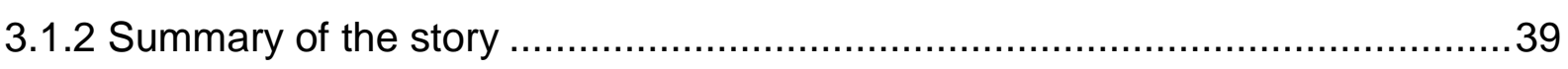

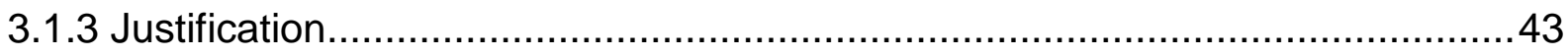

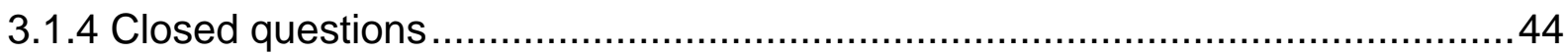

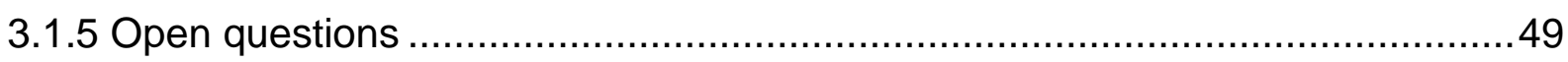

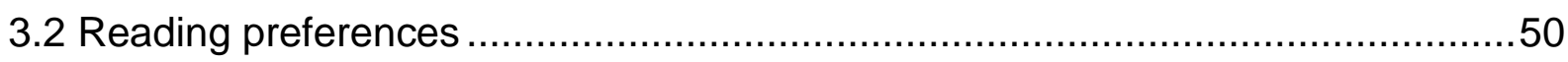

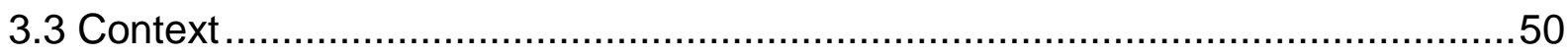

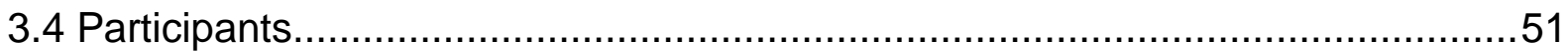

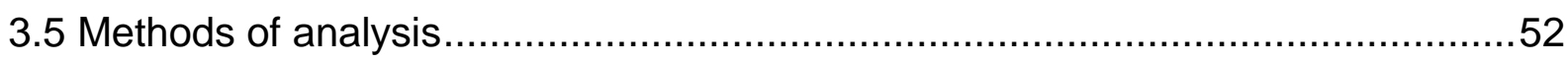

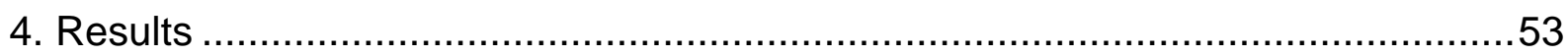

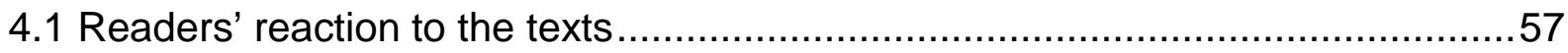

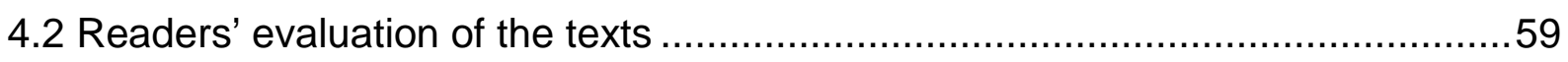

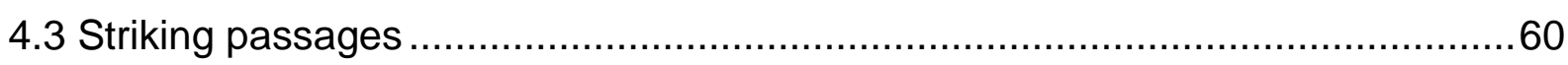

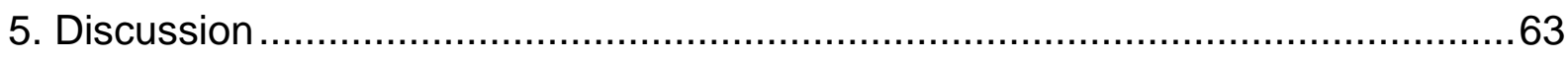

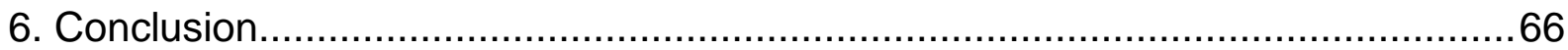

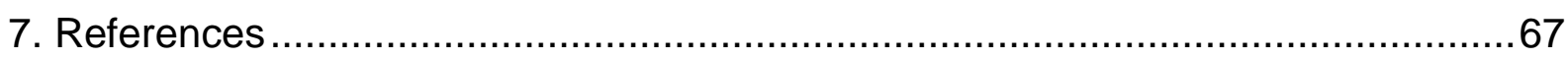

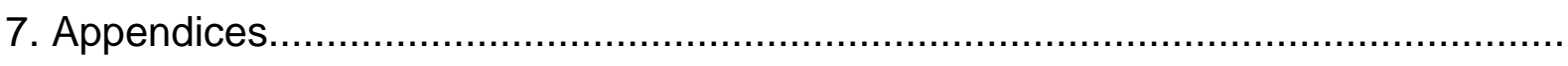

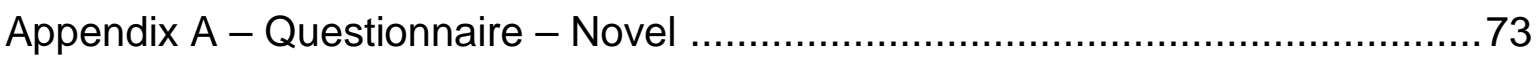

Appendix B - Questionnaire - Graphic Novel ............................................77

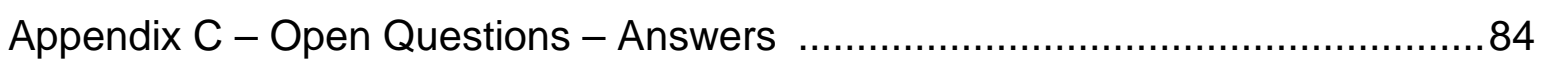




\section{List of Tables}

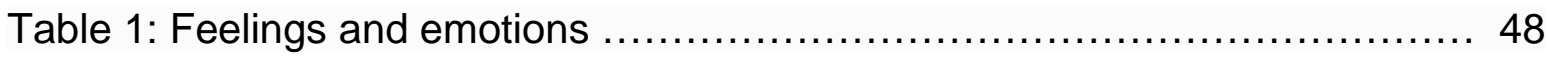

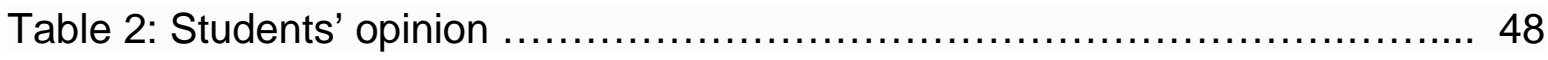

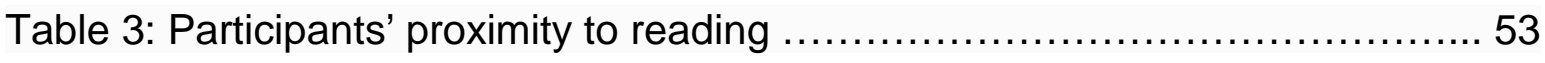

Table 4: Comparative analysis - Boys/Girls ............................... 54

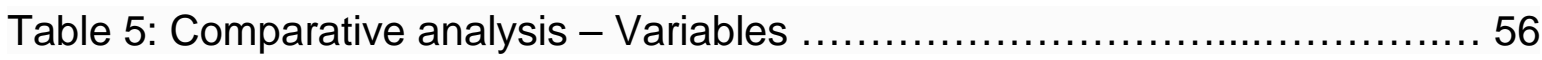

\section{List of Figures}

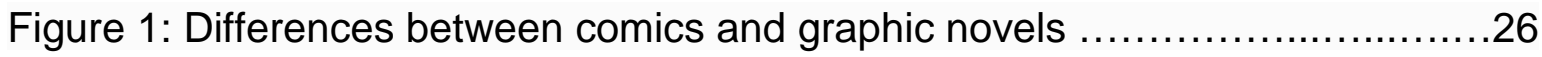

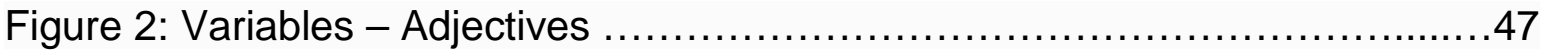

Figure 3: Personal reaction - Feelings and emotions $\ldots \ldots \ldots \ldots \ldots \ldots \ldots \ldots \ldots \ldots \ldots$

Figure 4: Reaction to the text - Students' point of view ....................... 59 


\section{Introduction}

Involving students in reading can be quite challenging. If not reinforced, it may have negative consequences to their lives. A survey carried out by the Instituto Ayrton Senna in 2013 reveals that $40 \%$ of the Brazilian students conclude their elementary school studies with severe problems in reading comprehension in their mother language. If they do not read in Portuguese, would the situation be even more dramatic in a language they do not master, such as English?

This situation is not new. When I was in school, reading for me was one of the best activities teachers ask students to do, but not everybody shared the same opinion. In fact, some of them were quite reluctant to read any type of text. The books chosen by the teacher or by the school were not interesting and the topics were most of the time not appropriate for our age. When I became a trainee, nothing had changed. The teacher asked students to read books aiming at a test. So, for students, the only and main objective in reading a book was to answer questions to prepare for examinations.

Finally, when I became a teacher, I noticed a slight difference. Some students showed more interest in reading but there were still others who did not even read short texts. When they had to read, they complained and were quite upset. According to Soares (2015), reading has become an automatized activity in which students do not know what they are reading or why they do so.

Reading is a necessary activity for the development of critical individuals. However, attention must be given to the kind of text used which may help the teacher motivate students and change the current situation. Teachers, on the other hand, should be aware of students' needs and interests by selecting the type of books they like to read. Maybe, if students have the opportunity to choose the books they would like to read, it may give them a different point of view on reading activities. 
In this monograph, I move in this direction and present an unconventional text to be used in the classroom which may motivate students: graphic novels. This type of text presents images, short sentences and dialogues, and may be more engaging. They are just like books but in a different format. They resemble comic books as both texts are formed by images of the settings and the characters and by the dialogues in bubbles. In graphic novels, words and images are linked, making it simpler and easier to read, which may increase vocabulary and comprehension abilities, especially of young readers.

Having said that, these are all conjectures. We must see if these statements hold true. Therefore, in this monograph, I will examine how students respond when they read a graphic novel. The main objective is to find out if these publications actually stimulate reading. More specifically, the following questions motivated the development of this research:

- How do readers feel when reading graphic novels?

- Would these readers evaluate the graphic novel the same way they do with the novel?

- Would one of these types of texts present more outstanding passages than the other? Would it be noticed by the readers?

The theories which based this research will be presented in the next chapter. I will discuss graphic novels through the perspective of theories and previous studies, with special emphasis to its use in the classroom. In this chapter, Reader Response Theory and Foregrounding will also be introduced. In Chapter 3, I will explain in details the methodological procedures adopted in this study in order to answer the research questions. Results will be discussed in Chapter 4, while the conclusions of the present investigation in Chapter 5. 


\section{Review of literature}

Graphic novels are different from traditional book stories. They present characters in a livelier way, in colourful and black-and-white illustrations, and the text itself tends to be written in short sentences and dialogues, and organized in bubbles.

Nowadays, it is not difficult to find graphic novels that are brand new stories as well as literature classic adaptations, such as A Christmas Carol, Frankenstein, Pride and Prejudice and many others. It is believed that more visual texts, like comics, may help students appreciate literature and feel more confident in reading (BRENNER, 2015). According to Haines (2012), "The key to getting these learners to read is to engage their imagination and interest. Comics are a perfect vehicle. They break the texts into manageable chunks, which are supported by images. These images help readers increase their vocabulary through the connection between words and images."

When it comes to graphic novels, Lundy (2008, p. 70) mentions the possible benefits of this type of text in students' learning process. In his words,

"With graphic novels, the scaffolding necessary to build solid readers lies in the architecture of the genre. (...) The illustrations not only support the text; they are an integral part of the text. Students are given context clues within the subtle and sometimes not so subtle expressions, symbols and actions of the characters within the story. Vocabulary is also supported within the illustrations and the text.")

As it was always considered a means of entertainment, graphic novels are difficult materials to be introduced in classrooms. Teachers and educators need to be convinced that they do not present poor or bad language and may actually contribute 
towards learning. In the next section, I will present a brief history of graphic novels and then define them. This discussion will be followed by the use of graphic novels in the classroom and a justification for this study.

\subsection{Graphic Novel}

\subsubsection{Historical Background}

Since pre-historic times, human beings have tried to communicate through different channels, including images. From cave paintings to Egyptian hieroglyphs, through medieval tapestries as the famous Bayeux Tapestry and church paintings, drawings were used to communicate, to pass on rituals and myths, in sum, peoples' stories or culture.

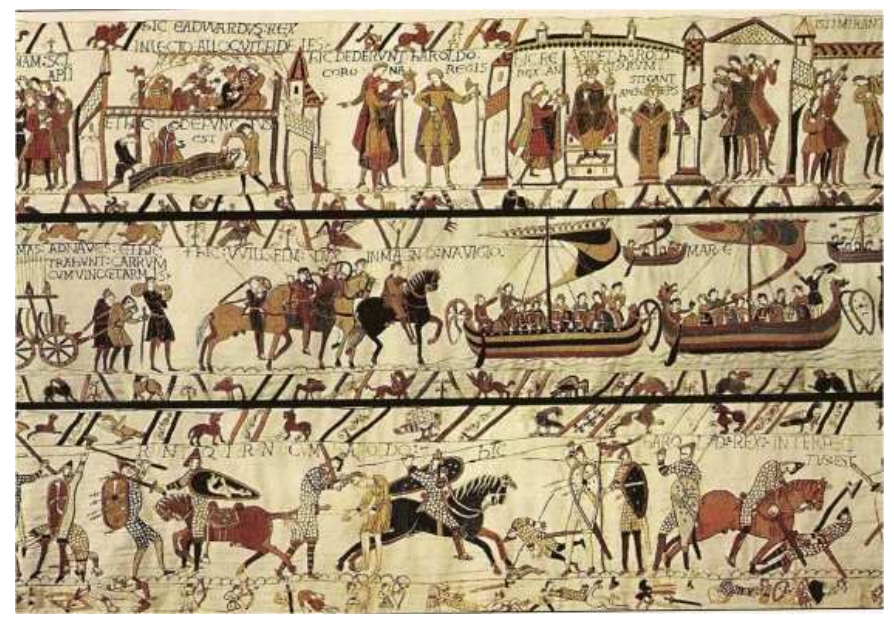

Bayeux Tapestry (Source: https://br.pinterest.com/pin/377598749977448910/) 


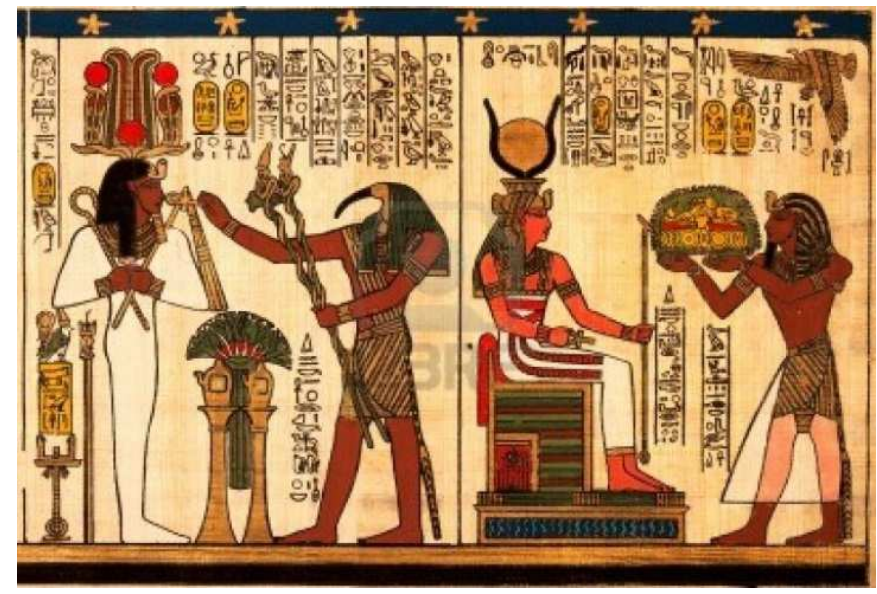

Egyptian Hieroglyphs (Source: https://elliecliftlands.wordpress.com/tag/egyptianhieroglyphs)/)

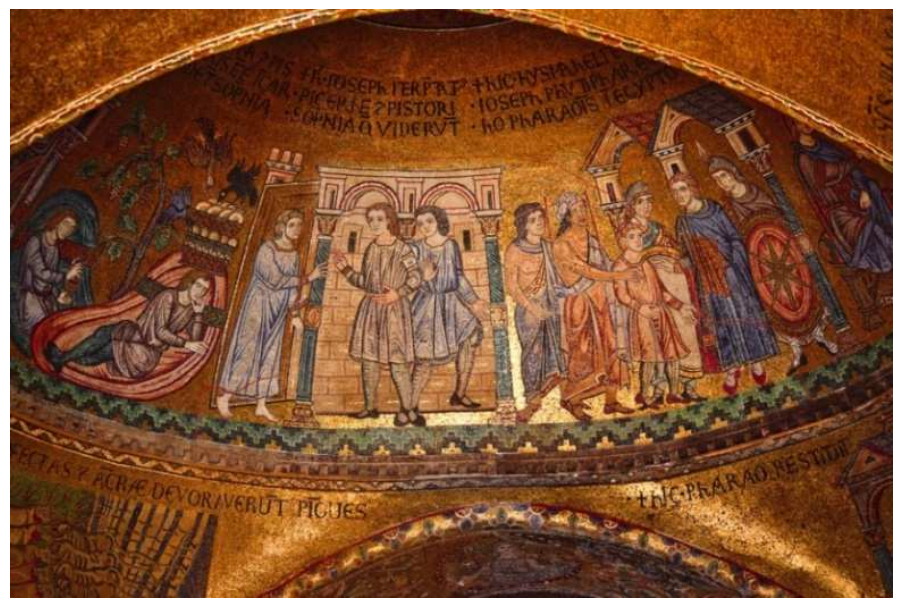

Mosaics in Saint Mark's Basilica in Venice, Italy. (Source:

https://www.walksofitaly.com/blog/venice/6-fascinating-facts-about-st-marks-basilica)

Individuals have relied on images especially as in the early years of civilization the rate of illiteracy was high. Only the wealthy or the religious had the right to learn. In the Industrial Revolution, however, access to education was made available and books were printed, enabling the dissemination of reading.

The rise of the newspaper industry also offered the readership a different format, in strips divided into boxes and the texts and dialogues were in balloons. That was how comics came into everyday households. In 1733, Benjamin Franklin printed Poor 
Richard's Almanac with various new stories in serial1 format. It was very popular and successful for 25 years.

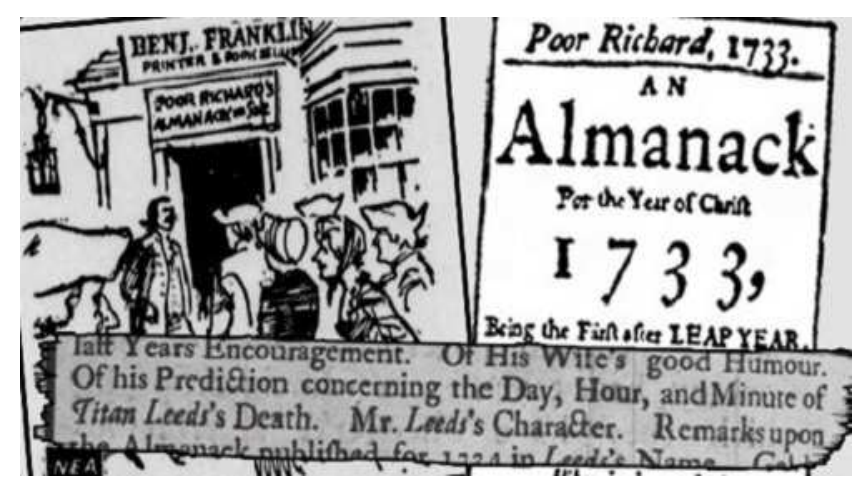

Poor Richard's Almanac (Source: http://www.benjamin-franklin-history.org/poor-richardsalmanac/)

In addition, it was also the age of the American Revolution, and, at that time, these comics or cartoons, as they were called at that time, played an important role in communication, because they conveyed information and messages about the war.

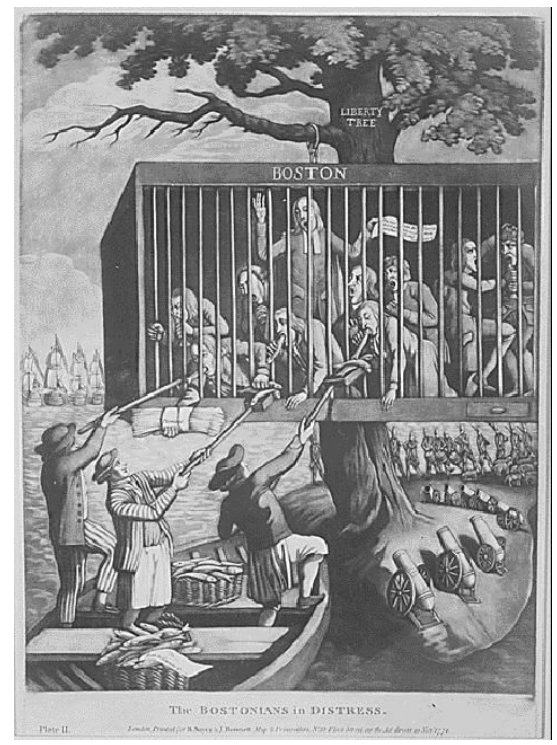

The Bostonians in distress. Cartoon in mezzotint, published by Sayer and Bennett, London, 1774 (Source: https://www.archives.gov/files/research/military/americanrevolution/pictures/images/revolutionary-war-061.jpg/)

${ }^{1}$ Serial is a story that is told in separate parts over a period of time. (Cambridge Dictionary) 
Afterwards, reading became not only a way to get education or be informed, but also for entertainment. Humorous and satirical cartoons were the most effective when mentioning politics or any criticism towards the government decisions. Later, other periodicals were released, as the Dime Novel Magazine, which popularized western characters such as Buffalo Bill.

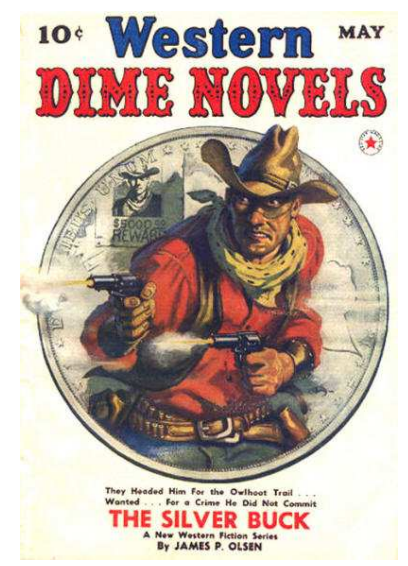

Cover of Western Dime Novels, 1940 (Source:

http://www.philsp.com/data/images/w/western_dime_novels_194005_v1_n1.jpg)

The first main graphic novel was published in the US in 1842. It was The Adventures of Obadiah Oldbuck, arranged in a weekly serial that told the story of a young man and his beloved one.

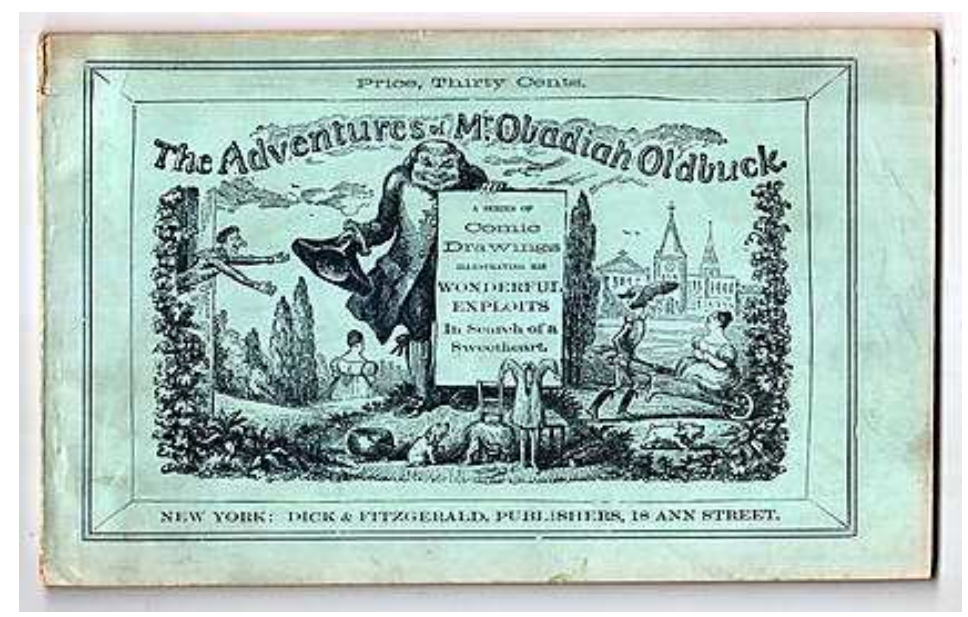

Cover of The Adventures of Obadiah Oldbuck, 1842. (Source:

http://www.thecomicbooks.com/old/Platinum.html) 
Then, in 1895 came out The Yellow Kid which was a huge sales success at that time.

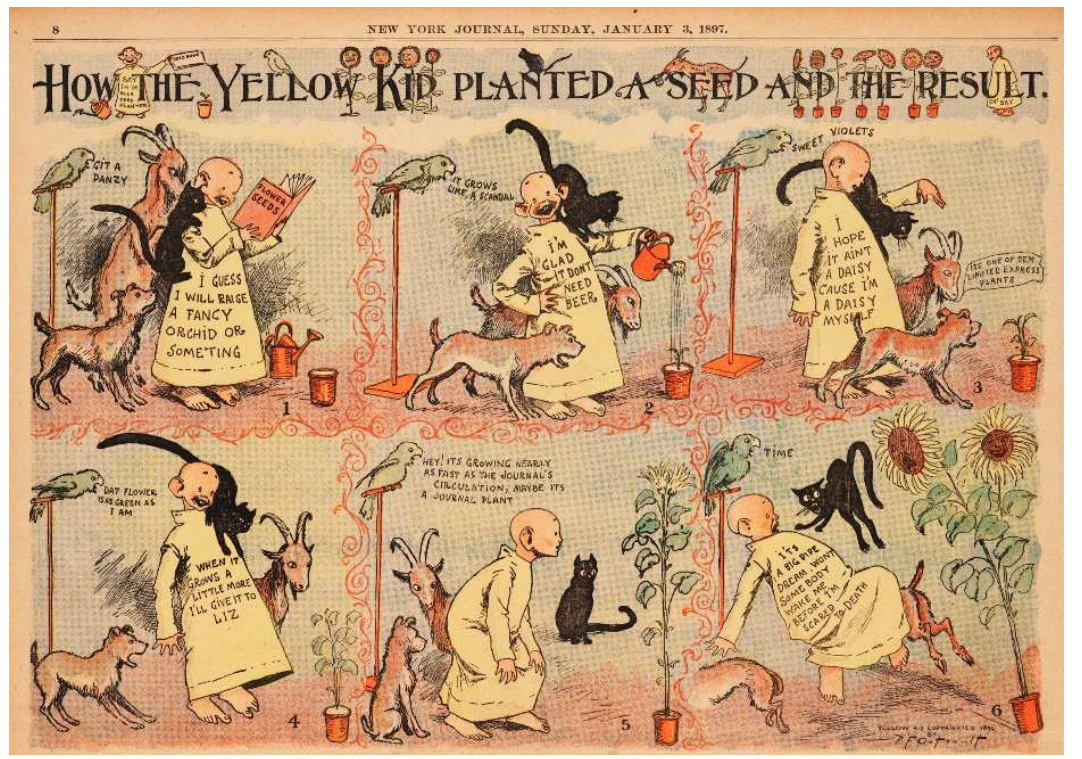

How the Yellow Kid planted a seed and the result, published in New York Journal, 1897. (Source: https://cartoons.osu.edu/digital_albums/yellowkid/1897/1897.htm)

Graphic novels also created heroes, as Superman in 1938, which was firstly directed to children, and then to adolescents and adults.

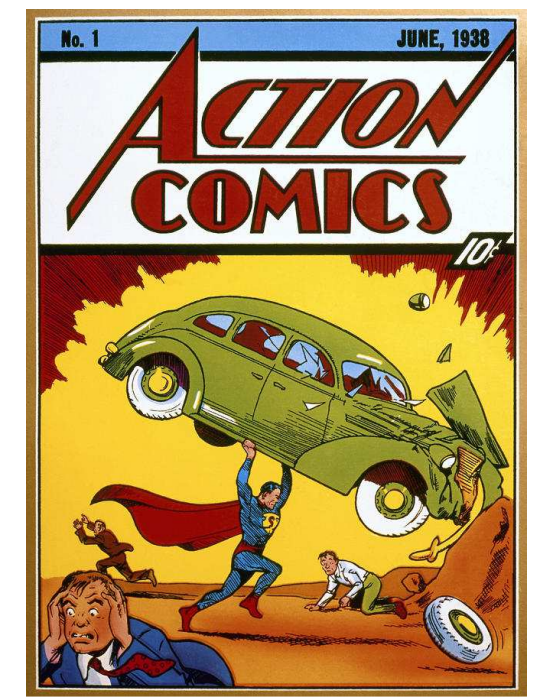

First Superman comic released, 1938. (Source:

https://comicvine.gamespot.com/forums/battles-7/1938-superman-vs-current-superman$1685059 /)$ 
Batman was released the following year in the Detective Comics No. 27.

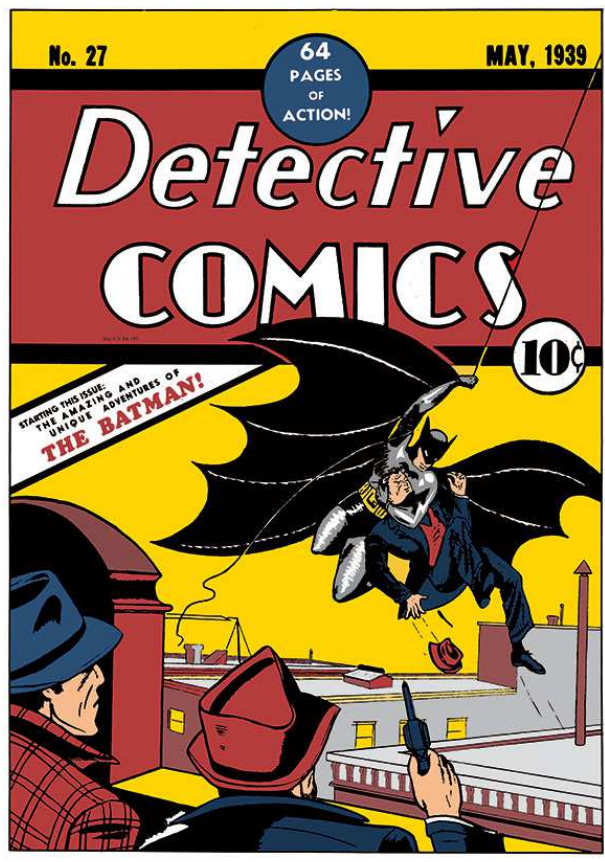

Cover of Detective Comics releasing Batman, 1939 (Source:

http://www.dccomics.com/blog/2014/07/22/batman-at-75-highlights-in-the-life-of-the-capedcrusader)

In 1950, a new revolutionary advent entered everyone's houses: the television.

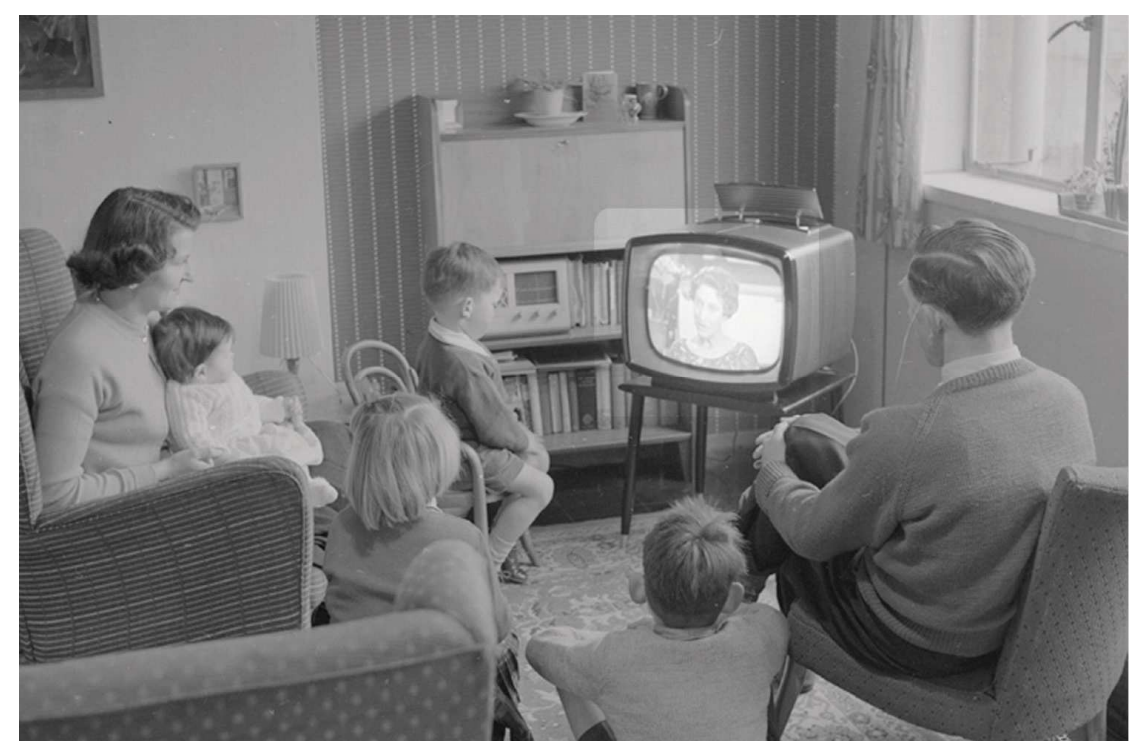

(Source: https://br.pinterest.com/pin/390265123947557933/) 
During this time, people started to question whether comics were still suitable for children. The adult view of comic books changed from general acceptance to distrust and fear for the moral wellbeing of children. Wertham (1954) stated in Seduction of the Innocent that comic books led to criminal activity, sex, destruction, homosexuality and overall juvenile delinquency (HAUGEN, 2005).

In 1960s, during the rise of the civil rights movement, comic books took on a new form in "commix" that served as underground readings for many organizations. At the same time, comics began to regain some popularity and acceptance. (MORRISON, BRYAN \& CHILCOAT, 2002)

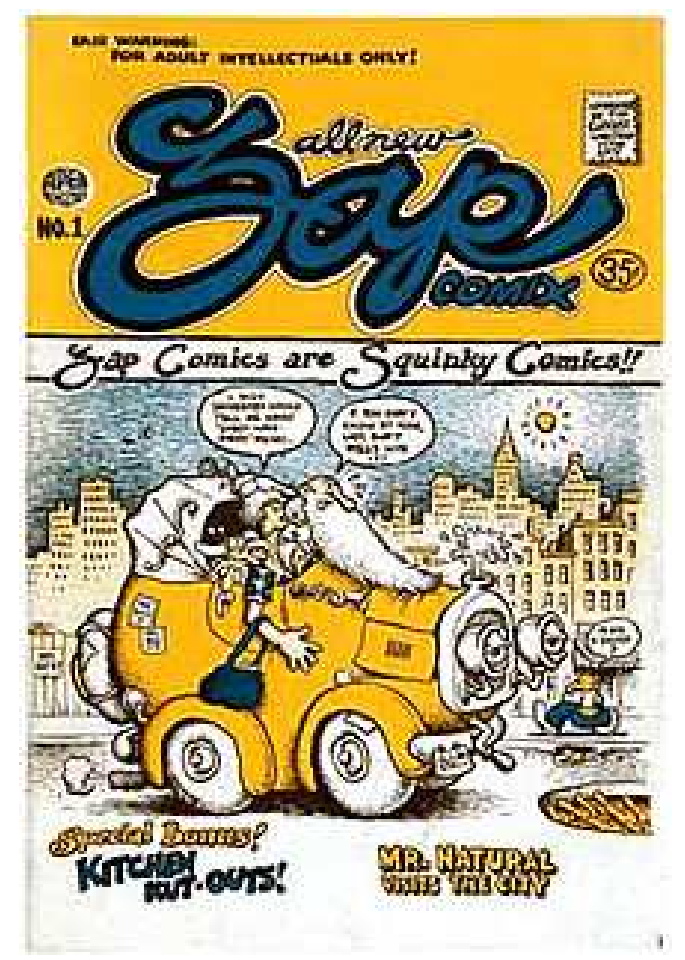

The cover of Zap Comix, 1968. (Source: https://en.wikipedia.org/wiki/Zap_Comix)

In 1978, Marvel Comics produced first original graphic novel. Written by Stan Lee and Jack Kirby, The Silver Surfer was released. (Encyclopaedia Britannica) 


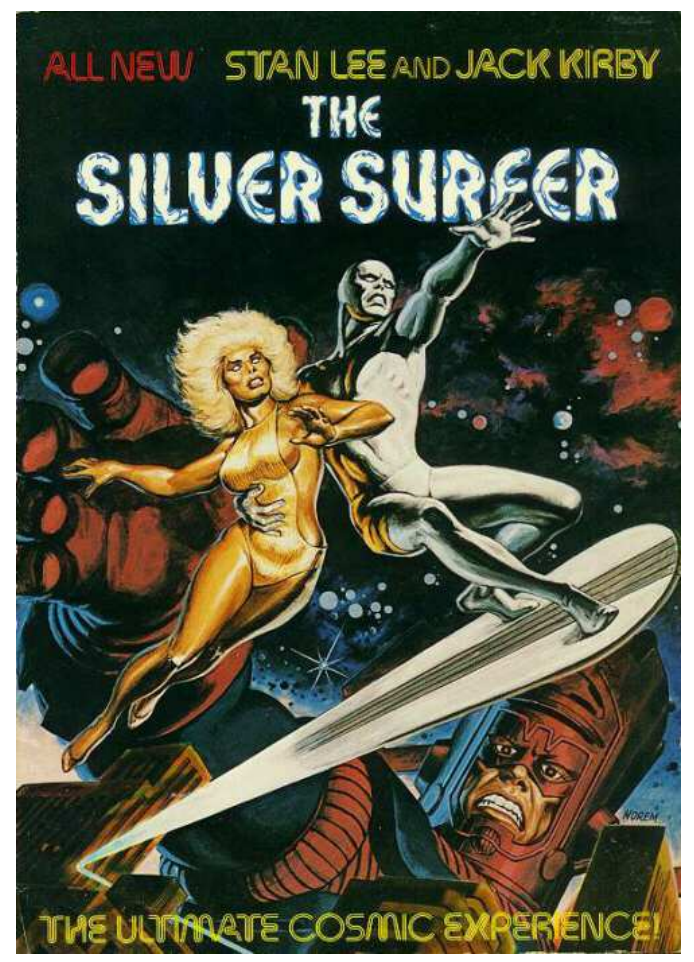

Cover of Silver Surfer, released in 1978. (Source: http://marvelite.prohosting.com/)

Following Marvel, there was also Sabre, by Don McGregor and Paul Gulacy

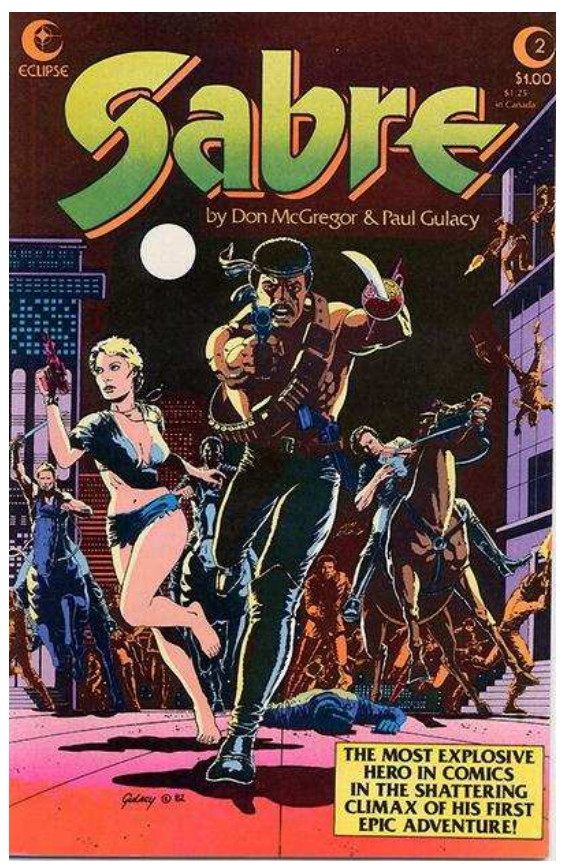

Cover of Sabre, first published in 1978. (Source: http://www.donmcgregor.com) 
and the famous $A$ Contract with God, by Will Eisner

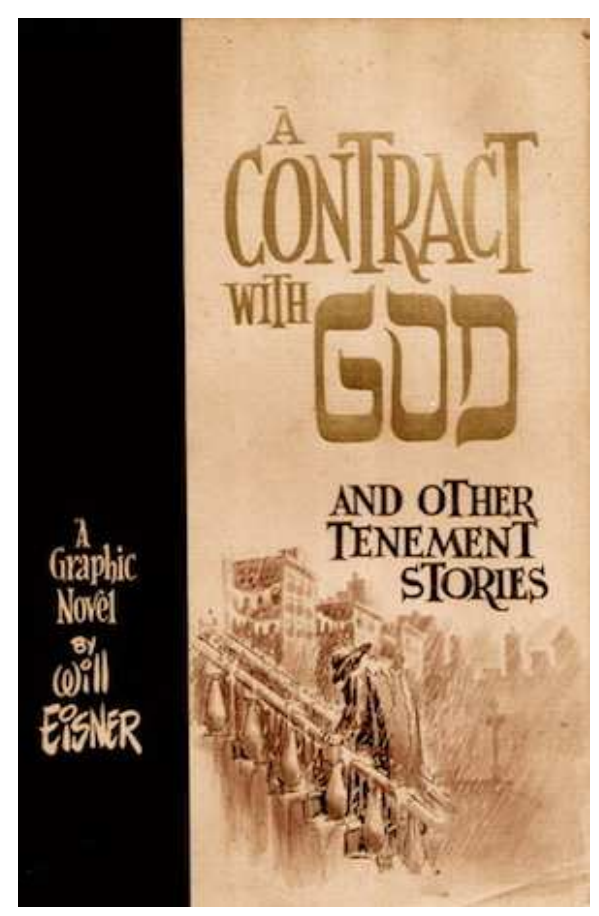

Cover of Contract with God, published in 1978. (Source:

http://www.vulture.com/2015/10/will-eisner-graphic-novels-paul-levitz.html)

Then in 1985, DC Comics released The Watchmen, which is the most bestselling graphic novels of all time.

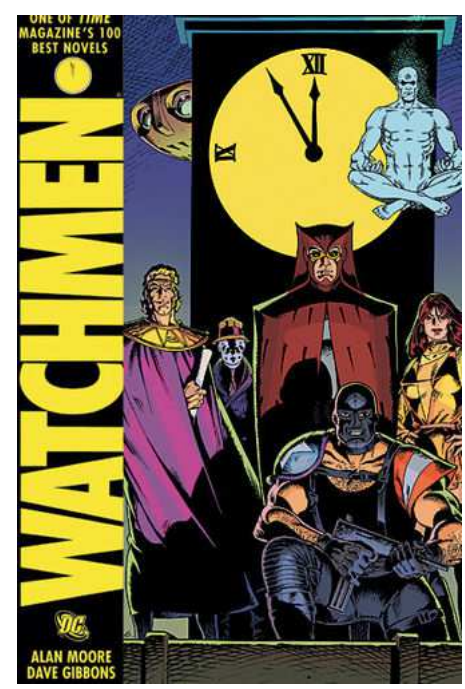

First publication of Watchmen, in 1986. (Source: http://dc.wikia.com/wiki/Watchmen) 
Noticing the huge success and popularity of graphic novels, other artists got involved in producing their own. Art Spiegelman released Maus: A Survivor's Tale. It tells the story of Spiegelman and his family in World War II during the Holocaust. It used postmodern approach representing Jews as mice and Germans and Poles as cats and pigs. It was the first graphic novel to receive a Pulitzer Award in 1992.

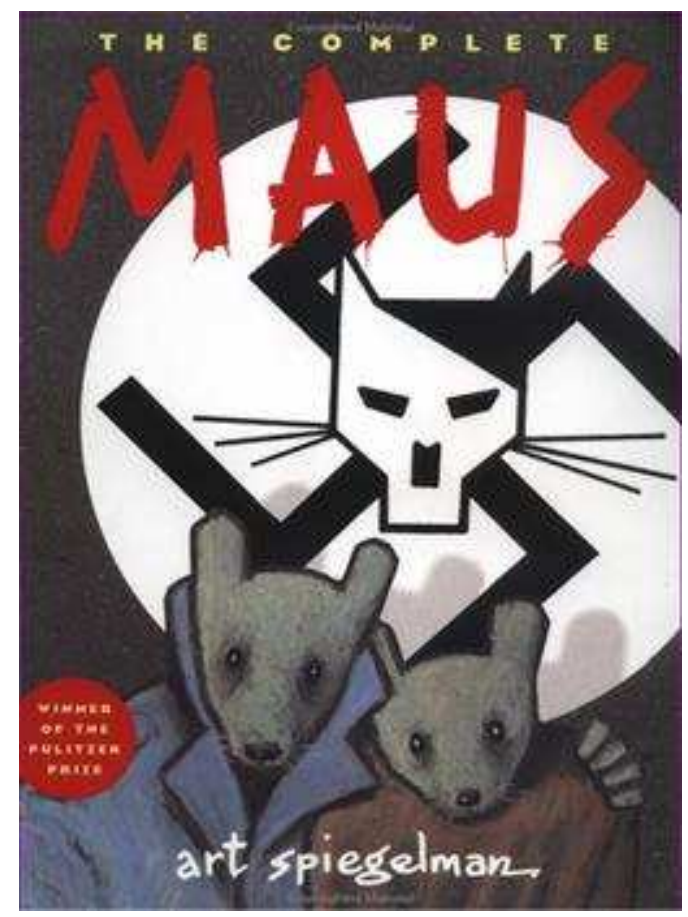

Art Spiegelman's Maus. (Source: https://bookarahma.com/category/war-series/)

Many other different comics and graphic novels have been released since then, presenting different themes, new characters. Some of them more directed to children as Donald Duck and Mickey Mouse, and others more to adolescents and adults, as Superman, $X$-men and Spiderman.

In Brazil, comics had its importance as a channel of communication with people. Although its origin is not from South-America, Brazilian illustrators and writers created the strips. They were very common in papers, usually bringing criticism to politics by 
using the famous lampoons. The first drawing circulated in 1837 by Manuel de Araújo Porto Alegre, who later created a magazine of political humour in 1844.

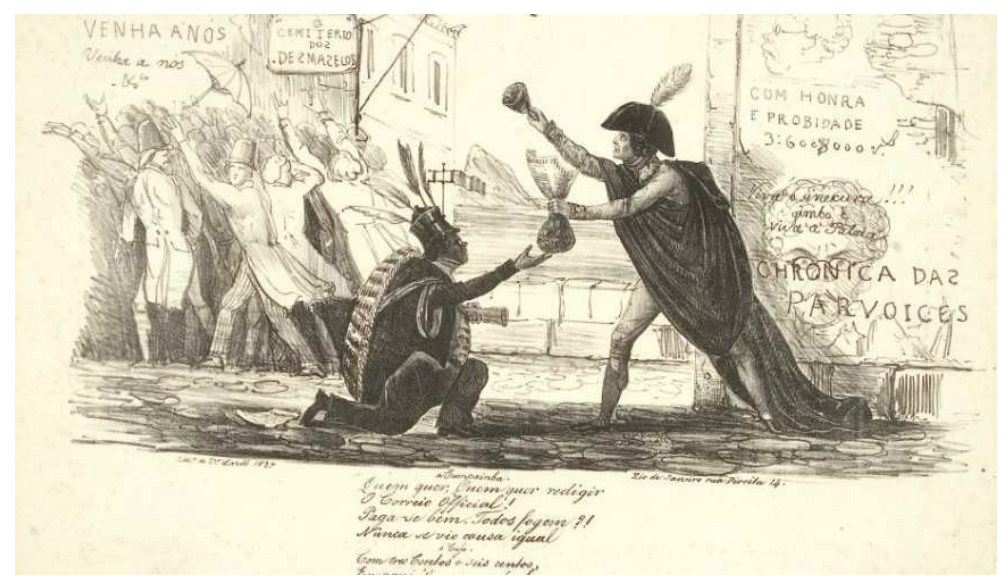

First Brazilian caricature created by Manuel de Araujo Porto Alegre in 1837. (Source: http://oficinadeartejackcartoon.blogspot.com.br/)

These drawings became part of the Brazilian journalistic popular publications, with Angelo Agostini's famous characters of that time as Nho Quim' (1869) (Quadrinhos Word Press)

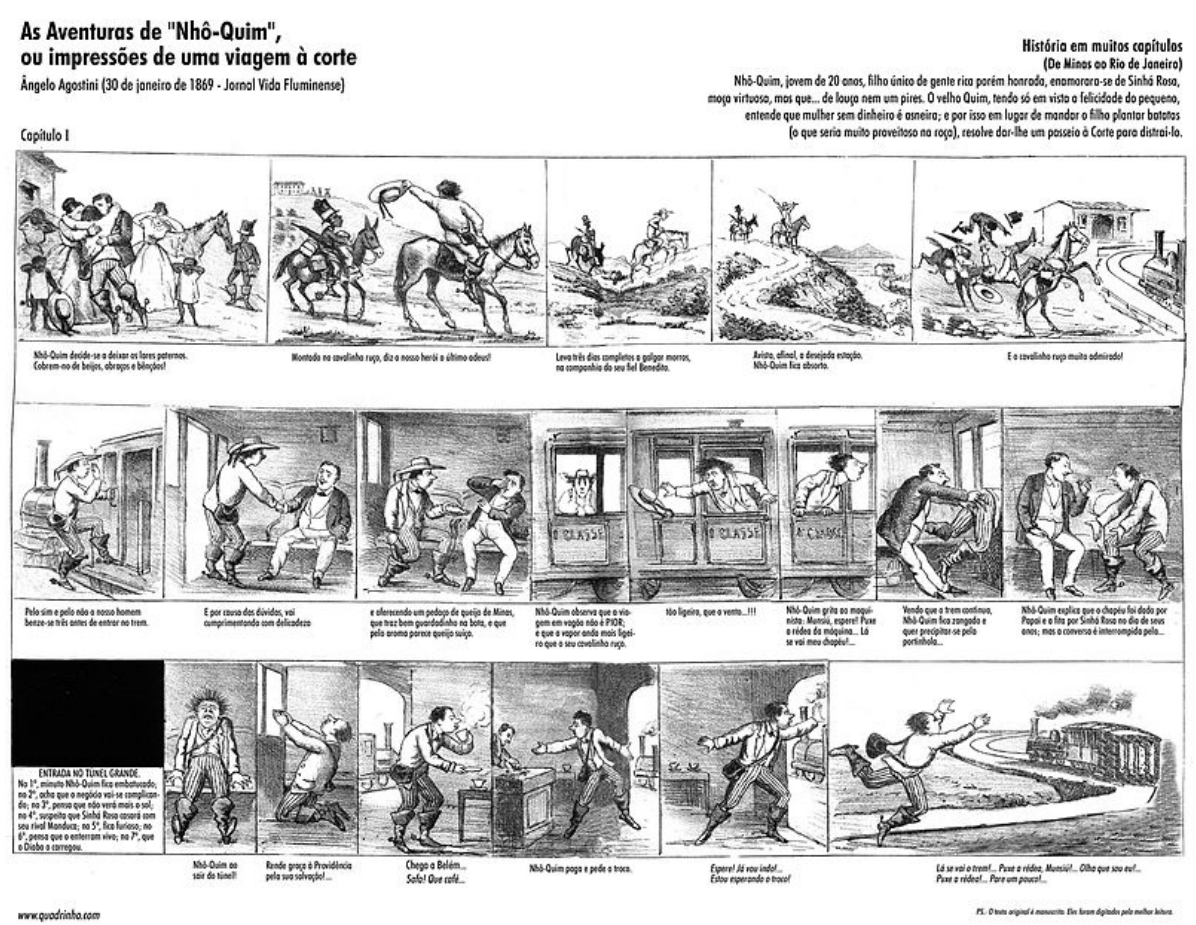

Brazilian comic As Aventuras de Nho-Quim, released in 1869. (Source: http://pingosemi.blogspot.com.br/2016/05/nho-quim-primeira-hq-brasileira.html) 
and "Zé Caipora" (1883).

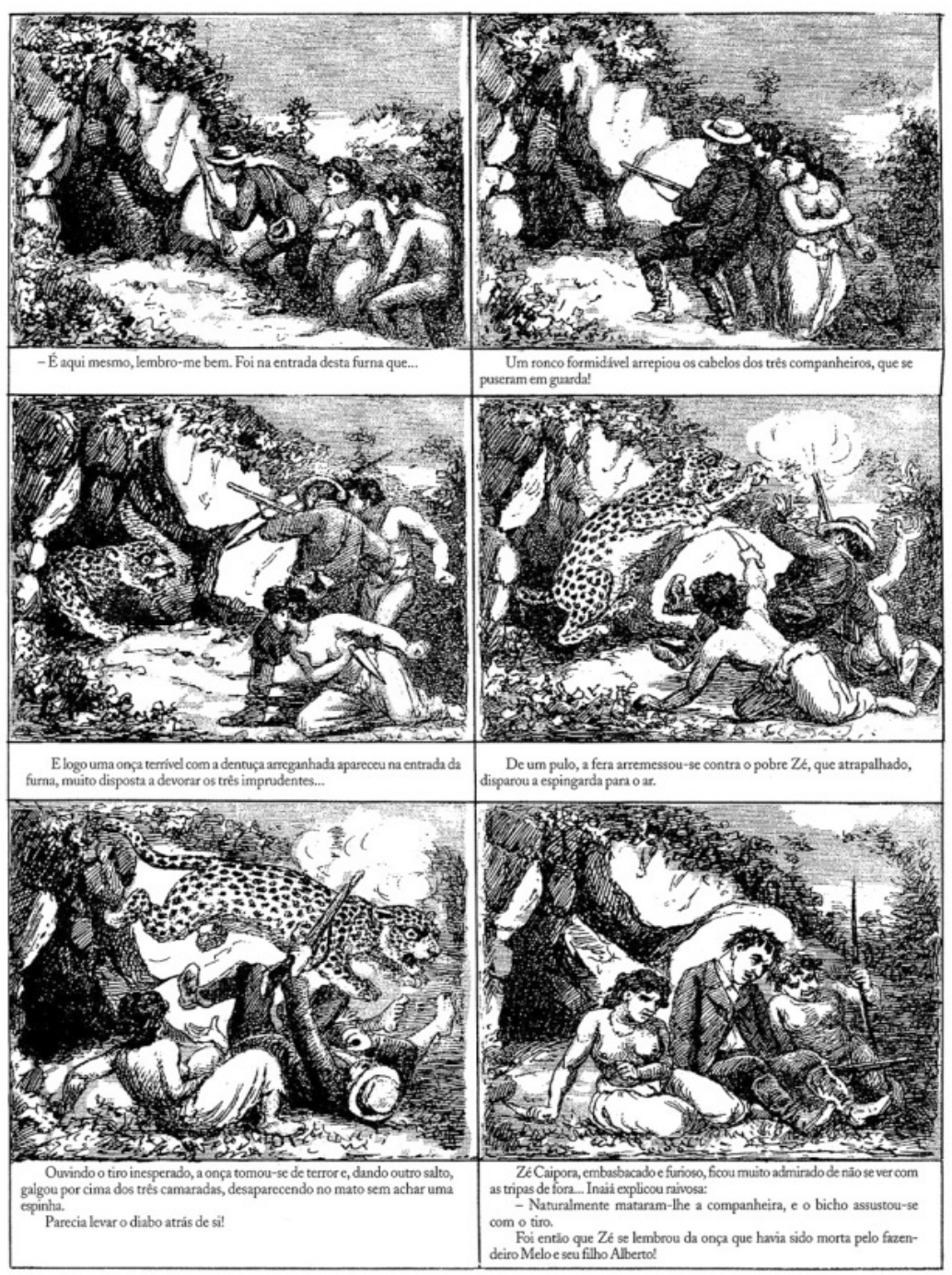

Brazilian comic As Aventuras de Zé Caipora, released in 1883. (Source: https://quadrinhos.wordpress.com/tag/as-aventuras-de-ze-caipora/)

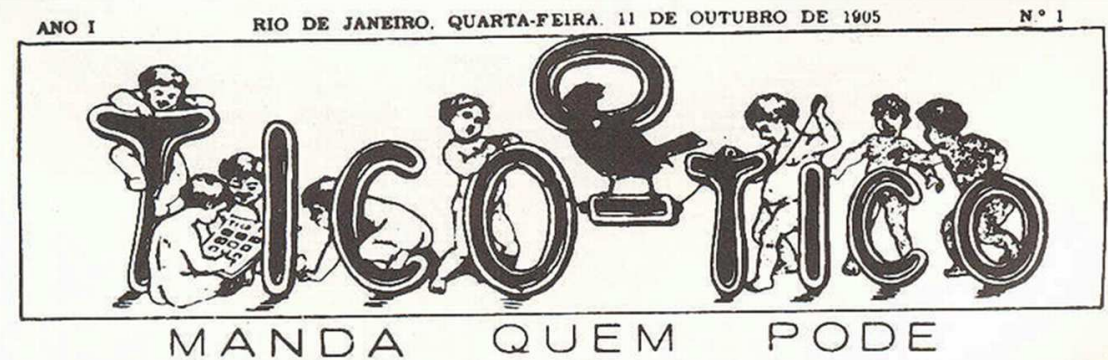

Tico-Tico was the first Brazilian magazine to publish comics, in 1905. (Source: https://pt.wikipedia.org/wiki/Hist\%C3\%B3ria_em_quadrinhos_no_Brasil\#/media/File:O_TicoTico.png) 
During the 60's theses strips had more importance than ever, as Brazilians were facing one of the hardest times in politics. During the military dictatorship, some publications, as $O$ Pasquim, which was against the military power, used to publish lots of strips in order to tell people what was really happening and what the government was trying to hide from them.

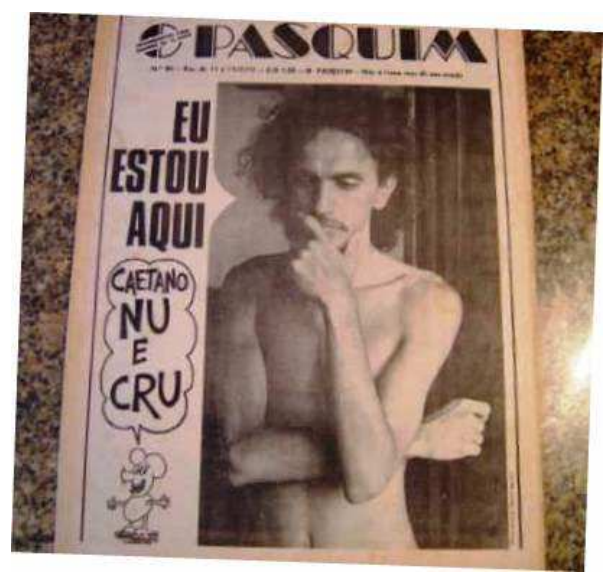

O Pasquim, published from 1969 to 1991. (Source: http://coisaseideias.com/wpcontent/uploads/2014/07/capa-de-pasquim-4.jpg)

Despite the political uses, comics were also taken as entertainment. In 1959, Mauricio de Sousa, one of the most famous Brazilian cartoonist started his work by creating Turma da Monica.

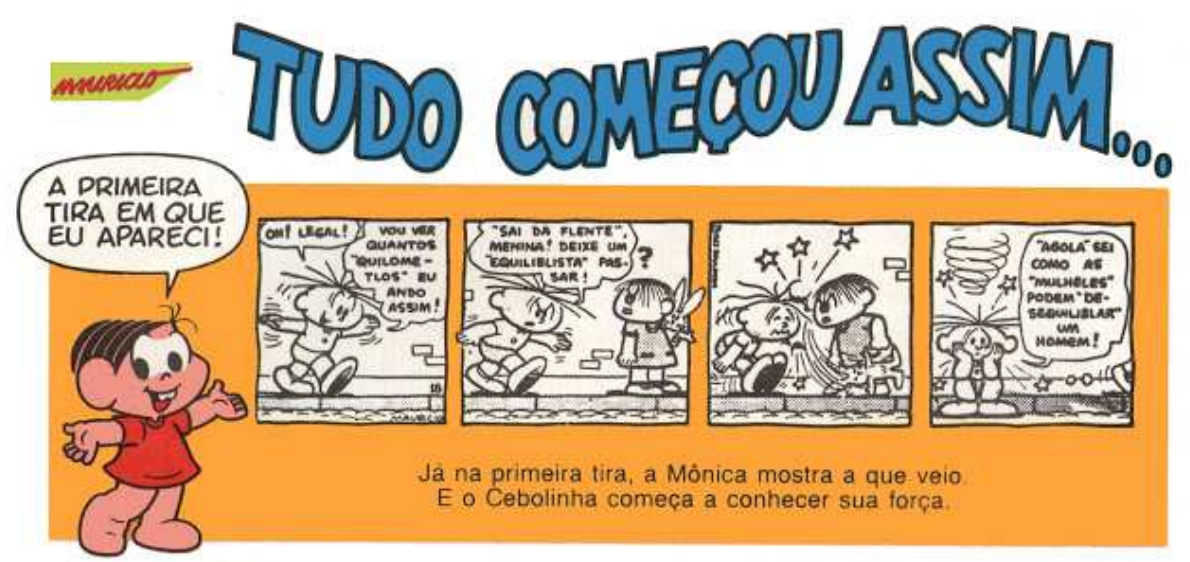

Monica's first appearance in 1963. (Source: http://www.lazcult.com/2013/02/nascidoem-1935-na-cidade-de-santa.html) 
It started being published in short strips, later it became a magazine, with different stories every week. Until today, Turma da Monica is one of the bestselling comics in Brazil, according to a research conducted by IVC (Instituto Verificador de Comunicação) in 2014.

Another famous writer and cartoonist also started his works during the 60's. Ziraldo created $O$ Pererê magazine.

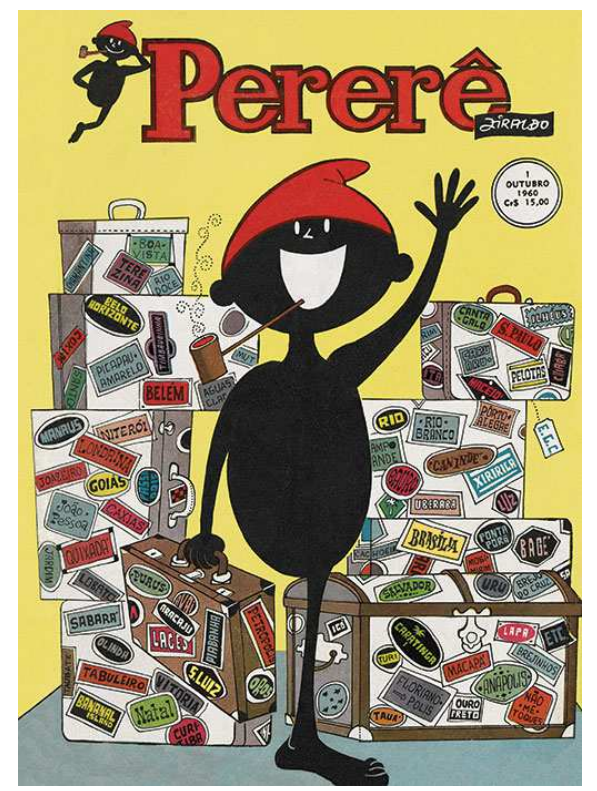

O Pererê, 1958. (Source: http://dalvaday.blogspot.com.br/2015/10/2015-historias-emquadrinho-do-saci.html)

Along with Ziraldo came Henfil who brought his famous characters Graúna, Os Fradinhos, Bode Orelana and so many others. 


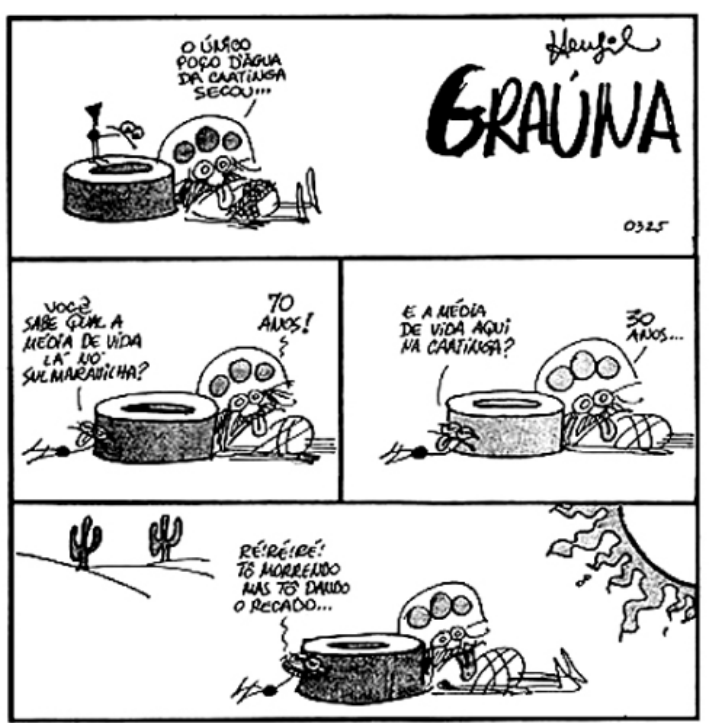

Graúna, strip used to be published in O Pasquim. (Source:

https://pimentacomlimao.wordpress.com/2010/02/07/lembrando-do-henfil/)

These materials have offered successful reading because they are cheaper than books, easy to carry and there is always a new story to be released. The popularity of visual texts, like comic strips and graphic novels, will continue to grow as they attract readers and present a variety of topics. In the perspective of Santos \& Ganzarolli (2011) the time has come for comics and graphic novels to take their place as valid literature in classroom.

\subsubsection{Definition of graphic novel}

To start with, it is important to distinguish comics from graphic novels. Comics are actually the basis of graphic novel as they use the same structure. Simply put, they are book-length comics. Some of them tell a single, continuous narrative; others are collections of shorter stories or tales. Many graphic novels emphasize drama, adventure, politics or romance. Some examples are Maus, by Art Spiegelman (see above), Archie, by Mark Waid, or Persepolis, by Marjane Satrapi. Readers have a wide variety to choose from, so readership is no longer limited to fans of superhero or humour. Not only can a graphic novel tell stories in comic format, but also tell a new 
story or present an adaptation of a traditional book. It may present similar details, content, plot and characters. The only difference is the way the story is presented to the reader.

Both graphic novels and comics use images, descriptions, text in balloons, coloured or black-and-white illustrations. However, there are some aspects that distinguish graphic novels from regular comics. Firstly, graphic novels are not released as a periodic, but they may have a sequence but never as a serial. Secondly, the length of stories is different. As most of graphic novels are complete stories, they are longer and the text and drawings are more fully developed.

On the other hand, comics are materials with a paper cover and the material used is of low quality. The story presented is always in continuous format. In other words, only a small part of the story is published in each issue, stimulating the reader to acquire the next comic book, which usually comes out weekly, monthly or quarterly. The following figure may make the distinction between comics and graphic novels more clearly.

\begin{tabular}{|l|l|l|}
\multicolumn{1}{c|}{} & \multicolumn{1}{c|}{ Comics } & \multicolumn{1}{c|}{ Graphic novels } \\
\hline Presentation & Panel-style and illustrations & Panel-style and illustrations \\
\hline Text & Speech balloons & Speech balloons \\
\hline Theme & $\begin{array}{l}\text { Different stories that usually continue in the } \\
\text { next issue }\end{array}$ & $\begin{array}{l}\text { It contains a set of tales or a single } \\
\text { complete story }\end{array}$ \\
\hline Storyline & Usually heroes vs villains & Different themes \\
\hline Length & It has no beginning point & $\begin{array}{l}\text { It has a beginning, a middle and an } \\
\text { ending parts }\end{array}$ \\
\hline Material & Short & Medium-Long \\
\hline Availability & Paper cover and staples to hold the pages & $\begin{array}{l}\text { Hardback cover and glue to hold the } \\
\text { pages together }\end{array}$ \\
\hline & Weekly or monthly released & Released once \\
Register & They are assigned an International Standard & $\begin{array}{l}\text { They are registered with an International } \\
\text { Standard Book Number (ISBN). }\end{array}$ \\
\hline
\end{tabular}

Figure 1: Differences between comics and graphic novels 


\subsubsection{Using graphic novels in classroom}

In 1944, the INEP Magazine published a study about comics and its value. The result was disturbing: comics were considered damaging, a material that was decreasing students' learning, as well as discouraging them. They overlooked regular books and the reduced texts lines and more images caused mental laziness. Therefore, until the 1980s, using comics or graphic novels in Brazilian schools was not recommended. Despite all that, Lundy (2008) highlights that comics bring exactly the opposite: they help readers to memorize, and more importantly, they stimulate readers to create.

Even though, comics are still difficult to be found in classrooms. Junior (2009), in his article Quem disse que os quadrinhos são inimigos dos livros? presents his thesis about the importance of comics in the education of readers during childhood. In this article, Vergueiro, coordinator at the Center for Research on Comic Books at ECAUSP, mentions that most of times this is due to the lack of awareness of teachers, who do not know how to choose the appropriate comic books nor how to use them in classroom. He states that the idea that comics would cause mental laziness was already proved by other studies as wrong and that the use of comics in classroom would make students more confident in reading. According to Vergueiro (2009: 02), "The broadening of the familiarity of reading comic books in the classroom leads many students to open up to reading and find it less difficult to concentrate on reading the necessary material for learning purposes".

It was only in 1996 that legislation (Lei de Diretrizes e Bases) included comics as suitable material to be used in classrooms, promoting their value in school contexts. Some years later, comics started to be accepted, sometimes just to illustrate a point, 
other times only to explain an exercise. However, this was a huge improvement considering that it is quite difficult to change some aspects in the educational area.

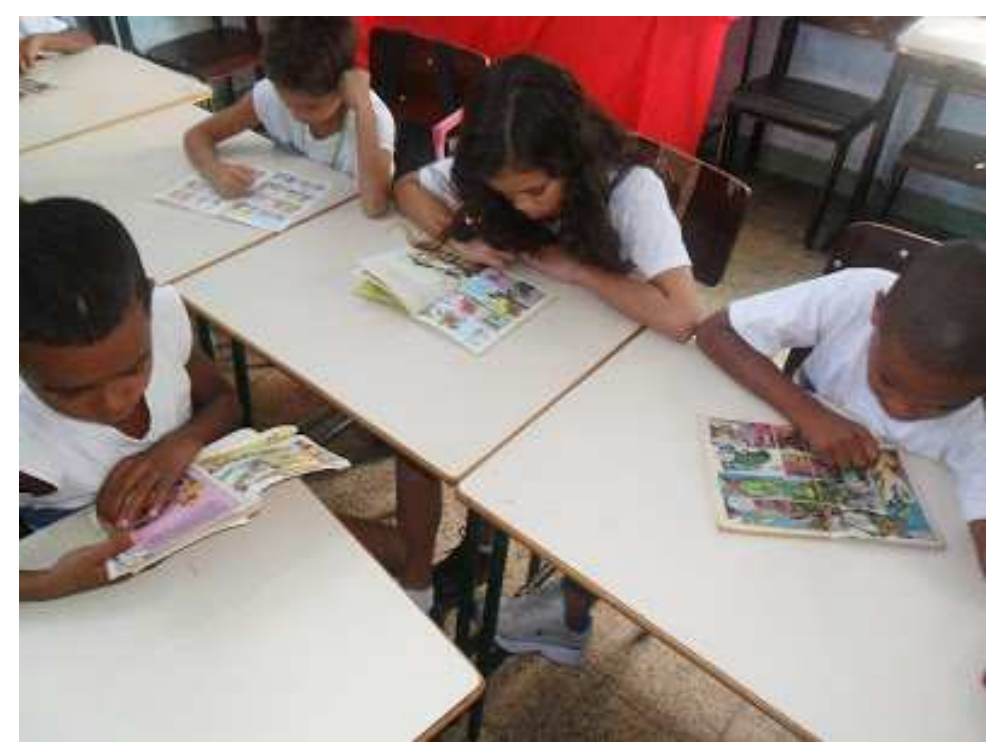

Third grade children reading comics. (Source:

http://projetandonaeducacaoinfantil.blogspot.com.br/2013/05/10-dicas-para-trabalhar-emsala-de-aula.html)

Some of the pros of using more imagistic texts is that presenting different materials promotes students' transition into lifelong readers, as suggested by McQuillan (1998: 86): 'Providing a rich supply of reading matter to children of all ages, as well as a place and time to read, is first step to bridging the gap between poor and good readers."

On the other hand, there are some authors who do not believe that graphic novels can be good reading material and be used as support tool in teacher's everyday class (LOPEZ-ROBERTSON et al., 2011). In Brazil, this view has changed. Comics and graphic novels have become so common in the classroom that they can already be found in the school's libraries, mainly because in 2007 books in comics format were included into the library collection that was distributed to schools. 


\subsubsection{Justification}

As in every school, teachers will always find students who present difficulties in one or another subject. The school I work at is not different. Some children are good at dealing with numbers, others excel at working with formula and calculus. However, many of them have difficulty when it comes to reading activities and end up avoiding them.

For some students, the link between reading a text and learning can be difficult for many reasons. Part of this group struggles with comprehending written text, others are not interested in the typical classroom reading material. Considering that reading is highly important to develop skills such as writing, and acquiring a second language, English classes should not be focused only on teaching grammar rules.

In order to sensitize students to reading, I assumed that presenting different materials would help them overcome their resistance to reading. Newspapers, magazines, even movies were considered, but they did not show interest in the topics provided. As they have to read literature classics as part of the school curriculum, reading was crucial. I decided to adopt the strategy to make them read without telling them they had to read. In order to do this, I had to find attractive material, something that would not look like a traditional book, that they would be more interested in and that they would be familiar with.

Their learning process also had to be considered. According to Gardner's (2011) theory of multiple intelligences, each child has different needs and learns at a different rate. Thomas (2012) also reminds us that students come to class with different backgrounds, interests, languages, strengths and weaknesses. So, giving classes just to follow the school syllabus regardless of the students' needs generally ends up affecting negatively many other areas. 
My aim was not only to make students read, but make them read literature classics, which was even more challenging. As Gorman (2003) states, students who have reading difficulties are often reluctant to read and lose interest in literature. So, the objective, by presenting students a classic in a graphic novel format, was to observe and analyse their responses. Depending on their reactions, I would be able to check whether this material was valid to be used in my classroom or not. This research is also about motivating advanced and reluctant readers. In The Power of Reading, Krashen (1993: 47-48) discusses the importance of popular fiction for young readers. According to him, "the most powerful way of encouraging children to read is by exposing them to light reading, a kind of reading that schools pretend do not exist and a kind of reading that many children, for economic or ideological reasons, are deprived of."

This view is not easy to apply at schools, as many of them still hold traditional teaching methodologies and they are not open to new ideas. When it comes to suggesting graphic novels as additional materials to be used in classroom, rejection is the norm (LUNDY, 2008). This is due to the old belief, mainly from traditional teachers, that the reading level of graphic novels is too low, the subject matter is frivolous, the language is too violent. However, it should be highlighted that there is a wide variety of graphic novels, as there is a wide range of books. So, depending on the theme one chooses, the book or the graphic novel will present different possibilities.

In some schools, teachers and coordinators are already aware of the fact that these types of materials should be part of classroom daily readings, because they noticed some improvements on students' works. According to Haines (2012), comics are perfect for students who face difficulties in reading because they present a simple and clear language, which would engage students' interest and imagination. 
Additionally, other authors do not agree that the language presented in graphic novels is poor and even states the importance of the combination between text and images. Images are a complex symbolic or semiotic system of communication (JEWITT \& KRESS, 2003) and one which young children invariably make use of in their literacy practices in and out of school. Researchers such as Barrs (1986), Dyson (1993) and Vygotsky (1978) emphasize the interconnection between image and text in children's works, where visual aids can be used as a means of interpreting printed words also as a platform for creating and communicating ideas.

In this work, the classic work used was Frankenstein, by Mary Shelley.

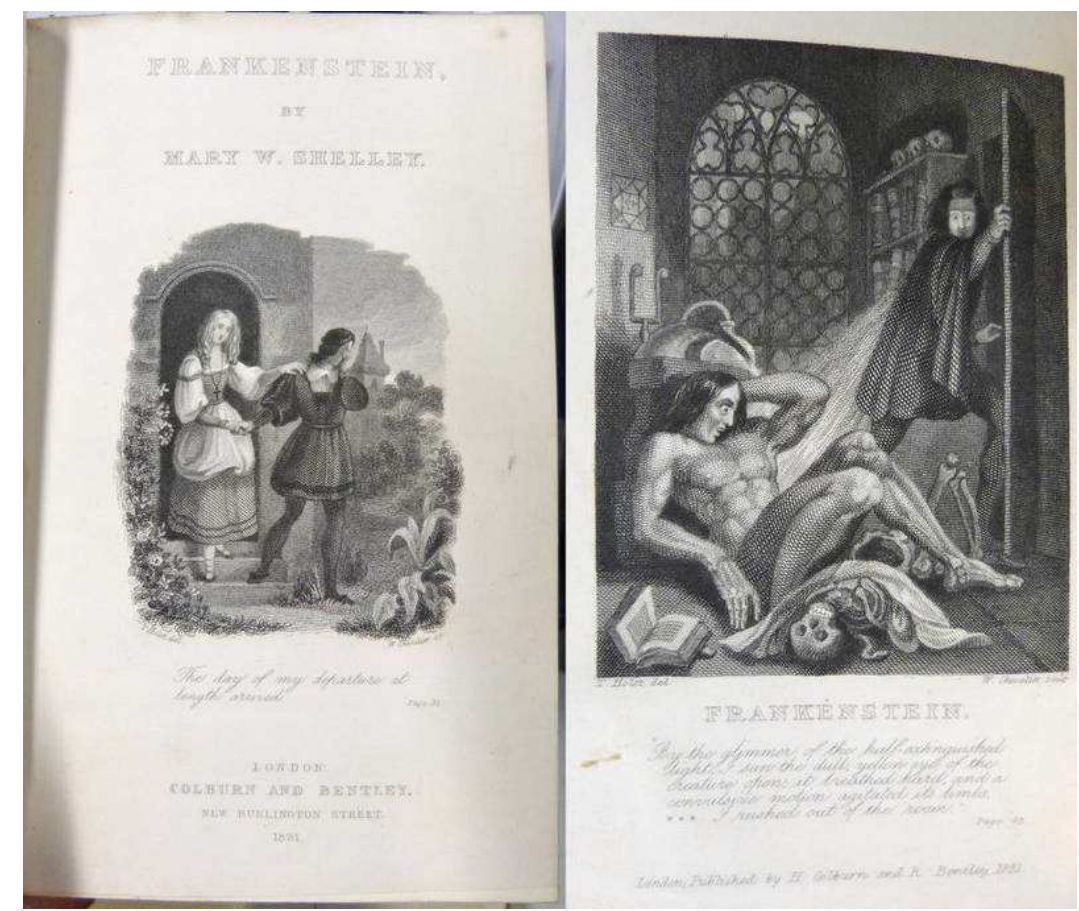

First publication of Frankenstein, 1818. (Source: https://www.the-saleroom.com/engb/auction-catalogues/taylors-auction-rooms/catalogue-id-srtay10039/lot-19af7270-ea8f4b05-b103-a56000ffb067) 
The versions used in this research were the following:

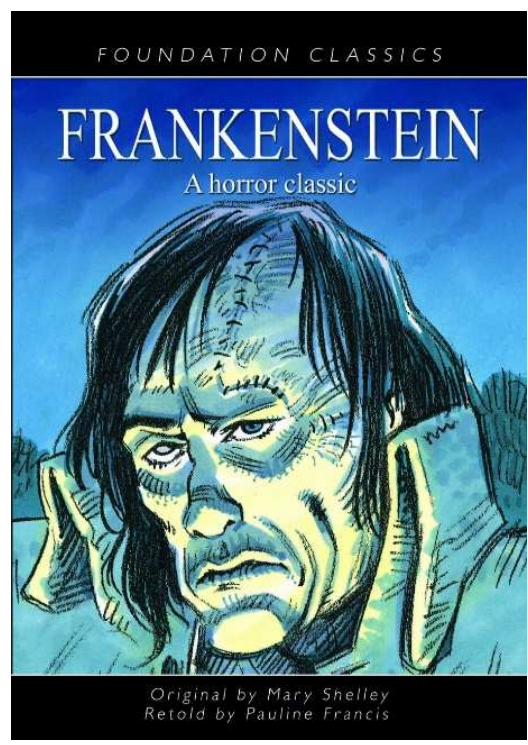

Book in novel format

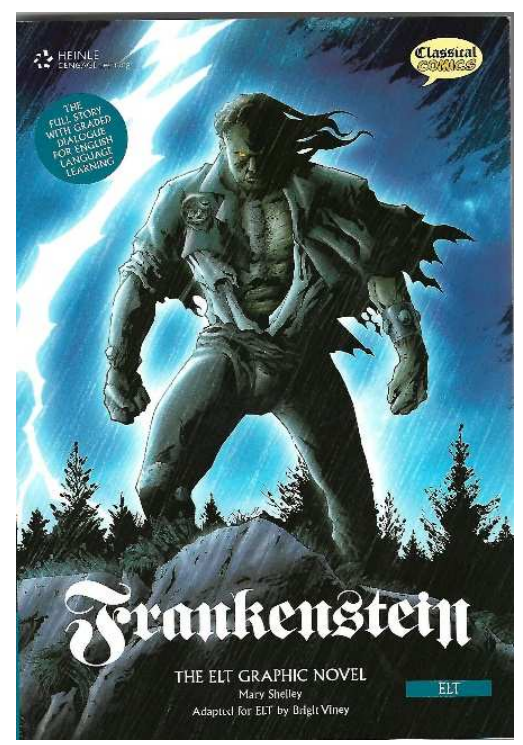

Book in graphic novel format

This work requires the reader to be actively engaged in the process of developing and comprehending a range of literary devices, including narrative structures, metaphor and symbolism, the use of alliteration, intertextuality and inference, that is, aspects that they would probably not be able to identify in a regular book. In addition, reading these classic stories in this format may lead them to read more challenging works in the future.

\subsection{Reader Response Theory}

To carry out the investigation, two theoretical pillars were considered. The first is reader response theory that tries to understand readers' reactions to texts. The second is foregrounding theory that focuses on features that stand out from the text, a characteristic that may draw readers' attention.

In order to investigate students' emotions and feelings when reading a canonical and a graphic novel, it was necessary to observe the experience the readers have when reading, their views and emotions. 
Reader response theory is actually a group of theories that emerged in the late 1960 's in the US and in Germany as a reaction to formalist theories such as New Criticism, which held that meaning was to be found in the text. Taking a different view, reader response theories hold that a text has no meaning until the reader reads and interprets it. Some of the theorists who shared this view were Louise Rosenblatt, Wolfgang Iser, Roland Barthes and Stanley Fish. They were against the idea of seeing textual works as objects, and highlight the reader's participation as the only way to give meaning to that work.

Louise Rosenblatt (1978) was one of the precursors of the movement. She argues that there is a transaction between the reader and the text during the reading process. In other words, the meaning of a given text lies in the reader's interaction with this text, rather than in the text itself. Still, according to Rosenblatt (1978) a text never has the same meaning for every reader, mainly because what should be considered is the reader's experience, beliefs, background knowledge and culture. As each reader presents a unique point of view, a different meaning will be given to that text. In her words,

"As with all texts, the reader must bring more than a literal understanding of the individual words. He must bring a whole body of cultural assumptions, practical knowledge, awareness of literary conventions, readiness to think and feel. These provide the basis for weaving a meaningful structure around the clues offered by verbal symbols." $(1978: 88)$ 
Instead of stating what is a right or wrong interpretation, readers should be free to understand a text according to what they see, bring out their point of view and only then provide their interpretation.

Later, A German professor of English and Comparative Literature, Iser (1974) focuses on the way readers use cognitive reading processes in order to interpret meaning in a text. According to him, there are two poles that involve the reader experience when reading a text: artistic pole, which relates to the text created by the author, and the aesthetic pole, which refers to the realization accomplished by the reader. Thus, the construction of meaning occurs between these two poles. Iser explains that "From this polarity, it follows that the literary work cannot be completely identical with the text, or with the realization of the text, but in fact must lie between the two."(1974: 274-275). In other words, meaning is realized through the act of reading.

Iser (1974) also mentions two aspects: the reader's role as a textual structure, that is, the reader's point of view, and the reader's role as a structural act, when the reader joins structured parts of the text converging them in his/her imagination.

From another perspective, Holland (1975) holds that interpretation is a function of a reader's identity which is revealed when he projects his emotions in the text. In Holland's words, "The only way one can ever discover unity in texts or identity in selves is by creating them from one's inner style" $(1975: 130)$

Different from Holland, Fish, an American literary critic and professor, argues that interpretation does not lie in reader's identity but in the principles and methods of the reader's interpretive community (FISH, 1980:171)

Similarly to Rosenblatt and Iser, Stanley Fish's individualist view focused on readers' experience and, according to their experiences, different interpretations will be given to the same text. These groups of readers or different communities are called 
interpretive communities, a concept developed by Fish in which he states that the meaning of a text will vary according to each group's knowledge and experience.

More recently, following the same line of thought, Miall \& Kuiken (1998) worked with reader's emotions and feelings, using concepts of foregrounding and defamiliarization, as will be discussed in the next section.

\subsection{Foregrounding}

Foregrounding is a technique responsible for making something stand out from a given object, photograph, or a painting. Not only in images, but also in the case of speeches, word or expressions may stand out and get more attention from the audience.

The definition offered by Routledge Dictionary of Literary Terms (2006) gives a more complete description. It says that, in Literature, "foregrounding may be most readily identified with linguistic deviation: the violation of rules and conventions, by which a poet transcends the normal communicative resources of the language, and awakes the reader, by freeing him from the grooves of cliché expression, to a new perceptivity". This gives the reader or viewer a way to analyse something through a different perspective, enabling them to notice aspects or characteristics they had not seen before (HAKEMULDER \& VAN PEER, 2006).

The notion of foregrounding was systematized by Russian formalists as Viktor Shklovsky (1965) who explains that art defamiliarizes objects to create a new perception, so that the viewer notices feature different from the ordinary ones. Then, when it comes to written works, the devices applied have specific purposes and are not there only to make the work fancy or to look more elaborated.

As Leech (1970) states, foregrounding can be realized by linguistic deviation and parallelism. Deviation is when expectations are broken, as in a text or a painting 
when they present something different from the usual, something that draws attention to a specific aspect of that work. It surprises the viewer or reader, who then has to interpret the text. Metaphor, metonymy and paradox, for instance, rely on deviation for effect.

Mukarovsky (1970) states that foregrounding is the intentional violation of the scheme by means of which an item is brought into active emphasis and thus stands out from its background. Still, according to him, using these linguistic devices demands a careful attention from the reader. The more an act is automatized, the less it is consciously executed; the more it is foregrounded, the more completely conscious it becomes. In the case of graphic novels, which is the main object of this study, this aspect can be easily found.

Reader Response and Foregrounding are the theoretical basis for the development of this research. In sum, foregrounding is related to the outstanding aspects the reader may find in the texts offered and reader response theory will support the understanding of how students react to these texts. 


\section{Methodology}

In order to answer the research questions regarding how students would feel when reading a graphic novel and how they would evaluate this type of text when compared to a novel, a questionnaire was developed which probed not only of students' feelings about the text, but also their opinions about it.

The quantitative part of the questionnaire involves the closed questions while the qualitative part refers to the open ones. The combination of both views, qualitative and quantitative, provides a deeper view in the way students perceive different types of reading material, as one of these texts, the graphic novel, which is not familiar to them.

In this chapter, I will show the aspects analysed and how this research was conducted. Firstly, the instrument used will be presented to clarify how the results were found. Secondly, the context where the research was developed will be presented, as well as its structure, location and facilities provided by the institution. Finally, details about participants will be reported as their age, English level, nationality and gender.

In addition, questions regarding students reading preferences were included to fully understand their views and opinions on the texts and to know more about students' reading profiles.

This presentation had to be done in three different days, one day in each class. On day one, the first group received the questionnaire with the graphic novel text; on day two, the second group answered the questions after reading the novel text; and on day three, the third group received both questionnaires, some students with the novel text and others with graphic novel format.

I informed them that they did not have to write their names, that the work was anonymous, emphasizing that their opinion and responses were the important aspects 
to my work. In addition, I explained that those questions were not a type of text comprehension test or any other school examination. I told them that those questions were about them (feelings) and about the text itself (their opinion).

Interestingly, students, with no exception, were all curious and anxious to read the text they received. There were some few doubts about vocabulary, but it was quickly explained and solved. Generally speaking, students read and answered the questions and no other doubts have emerged.

\subsection{Research instrument}

A printed questionnaire was chosen as an instrument to conduct this research for some simple facts. It is possible to collect a large amount of information and these data can be quantified by using statistical programs. And, most importantly, students were not identified, which might have made them feel more comfortable to give their own opinions. The questionnaire was organized as follows: the text (novel or graphic novel), closed questions, open questions, and questions on reading preferences.

\subsubsection{The text}

The main objective of this work is to analyse how students react when reading texts in two formats. Taking into consideration the difficulties many students face when reading any type of text, it would be even harder if they had to read an original version of a canonical text. Some of these works are not easy to understand and, depending on the novel, the language used may present complex sentence structure and infrequent vocabulary.

Frankenstein, written by Mary Shelley, was chosen mainly because of its main theme, which is the search for power and knowledge as well as the consequences of 
bad use of science. In addition, there are other aspects that may stand out, as the symbols of lightening and fire, the time in history the story takes place.

Additionally, the story itself, both graphic novel and traditional novel format, do not present difficult text language. In the novel format, there are some complex structures, that may probably bring some difficulty to students, but at the same time it is something they can handle. On the other hand, the graphic novel format presents images and texts combined in each panel; every image illustrated the action moments, dramatic scenes that are clearly perceived. The facts contained in the story and how it is told and presented in graphic novel format, was also a reason for choosing this novel.

\subsubsection{Summary of the story}

The novel opens with Captain Walton writing letters to his sister on his ship, while sailing north of the Arctic Circle. Throughout his voyage, one day his crew saw a figure shaped like a man but of gigantic stature on a sledge heading north, but it quickly disappeared in the ice. They could not understand what that huge figure was doing and where it was heading to in that cold foggy and icy place. Later, Walton's crew sighted another sledge, quite similar to the previous one, but there was a man on it. This man was weak, ill and could hardly speak due to the weather conditions and his exhaustion caused probably by the long quest he had been through.

After being rescued and slightly recovered, Victor Frankenstein, the man who was on the sledge, started to tell his sad story to Walton and explained how he was found lost almost with no life in that lonely place.

Victor Frankenstein came from a wealthy family in Geneva, Switzerland. As a grown-up man, he studied at the University of Ingolstadt, in Germany, where he was introduced to modern science, more specifically chemistry and natural philosophy. 
Very soon, Victor became obsessed with his scientific ideas and was eager to acquire more knowledge. He spent days and nights in his laboratory, trying to put his thoughts and ideas into practice. As any scientist, Victor searched for answers to his questionings, no matter what it would take.

This novel takes place during the Enlightenment or the Age of Reason, which was an intellectual movement in 18th century Europe. This movement questioned religious beliefs as well as the rise of concepts such as reason, liberty and scientific revolution. However, despite all the progress many areas had been through, some experiments did not give the expected answer to the scientist. Victor was searching for an answer that no one had ever found: the power of giving life. As previously in his life Victor had to deal with losses of beloved ones (his mother died when giving birth to his younger brother, William), he became obsessed with finding a way to bring someone dear to him back to life.

After some time, he became close to one of his professors, Mr Waldman, who was the only that shared the same views as Victor's. He believed that, by using the knowledge he had acquired and the experiments he had conducted, he would be able to give life to inanimate matter, the Galvanism effect ${ }^{2}$. His idea consisted of gathering remains of corpses put them together as to construct a human body. In order to give life to it, Victor set up a machinery that would attract the power of lightening during an electric storm. This electricity would give life to his creation. And it did.

However, as soon as the Creature stood up, Victor noticed the result of his insane experiment. It did not look like a human. On the contrary, it was completely

\footnotetext{
${ }^{2}$ The use of electric current to induce muscle twitches in dead tissue. Mary Shelley probably had in mind a widely discussed experiment of 1803 in which Giovanni Aldini had effected spasmodic contractions in the corpse of a criminal executed at Newgate prison
} 
different from anything he had seen. It had a huge figure, around 8 feet tall $(2.44 \mathrm{~m})$; his face was full of scars and stitches; his yellow skin contrasted with his watery eyes.

Terrified and not believing what he had done, Victor ran away from the laboratory and ends up sleeping in his bed chamber. But he is awakened by the noise of a thunder. He quickly notices that the Creature was right there, holding his hands up to him as asking for help. Victor then, leaves immediately and takes refuge in the court-yard, behind his laboratory.

Still hidden there and recovering from feverish illness, Victor receives a letter from his adopted sister, Elizabeth, informing that his younger brother had been murdered. As soon as he gets at his home, Victor goes to the place where his brother was killed and encounters the Creature there.

On that night that Victor had rejected him, the Creature left the laboratory and kept wandering around the city and through the forests. There he kept hidden in a small cottage to protect himself from the cold and from people around him. Next to his cottage, there was another one where an old man, his son and his daughter lived. The Creature watched and listened to them, learning how to speak. In addition, the old man, who was blind, was very kind and caring towards the Creature. But one day the Creature was found by the old man's family and was beaten.

Having nowhere to go, the Creature wanders sad and furious in the forest and sees, for the first time, his face on the surface of the lake. His appearance was completely different from everyone he had seen. Then, he understands why people hit him, threw stones and sticks at him. They were afraid of him and, even before getting to know him, everyone would reject him due to his distorted appearance.

In search of help, the Creature decides to look for Victor. While heading to there, he sees a beautiful child, William, and grabs him by the arm. The child yells that Mr. 
Frankenstein was his father and would punish the Creature. Full of hate and anger, the Creature strangled the boy.

When they finally meet, the Creature asked Victor to create a friend like him or a female as he is a lonely and unhappy "'man". At first Victor refused, but after thinking that the monster would follow him for the rest of his life if he did not do what the monster asked, he accepted the request. Before heading to England to finish his "'new" work, Victor sets his wedding date to marry Elizabeth.

Already in his laboratory, he felt he was not enthusiastic as in the first experiment, but he was nervous and restless. Even so, Victor follows the same procedures to make a new creature. As soon as he finishes building it, he thinks about the consequences it would bring if he really gives life to another monster. It could be worse than the first one, more violent and stronger. While considering all these facts, he noticed he was being watched. The Creature was watching him through the window all the time. The scientist, then, was sure about what he had to do. He could not make the same mistake again and, suddenly, he starts to destroy and tears the female monster to pieces. The Creature howls in despair and vows revenge, swearing he would come back on Victor's wedding night.

Later at home, Victor was already married to Elizabeth. Fearing the monster's promise, he sends his wife away and waits for him, thinking that the monster would come to kill him. The Creature appeared as promised on that same night, but killed Elizabeth. As the Creature could not have a companion, neither could Victor.

That is when Victor starts his quest to kill the one that has brought suffering and sorrow to his life. He follows the monster through the forest and mountains to the cold icy north. The monster was faster than Victor and quickly disappears in that freezing 
place, leaving no tracks behind. Exhausted and extremely sick, Victor is found and rescued by Captain Walton's crew.

At this point, the ice began to move, so the ship could continue its voyage to England. Victor did not restore to good health. He had difficulty to speak, even to breathe. The scientist dies some days later on Walton's ship. At midnight, Captain Walton hears a strange sound. He noticed then that the strange sound came from the cabin where Frankenstein's body was.

Walton steps into the cabin and to his surprise, there was someone weeping over Victor's body. Shocked, he noticed it was the creature that Victor was trying to find. The monster stares at the captain and tells him he is suffering, feeling alone and miserable, saying: "I shall die, I shall no longer feel the agonies which now consume me" (p. 266)

The monster leaves, heading north, gets lost in darkness and it was never seen again.

The novel was first published in 1818, the Age of Enlightenment, the time when science was progressing and it seemed that everything was possible. Behind Frankenstein's experiments is the search for ultimate power or godhood: what great power could there be than the act of creation of life?

The book shows not only the consequences the bad use of knowledge may bring, but also a reflection on what the limit of human's desire - or the lack of it - can cause.

\subsubsection{Justification}

Although Frankenstein was written in 1818, the texts used in both questionnaires were adaptations from the original text, which present a more suitable vocabulary and grammatical structures that made it easier for students to understand. 
The story was chosen considering the content and subject, the age appropriateness of this book for that specific group. As this research presents two types of texts, these had to be different from anything they had read. I was thinking of a literature work that presented some action, or something that would be interesting. This novel presents different moments of discovering, fear, terror, action, surprise. In addition, it was important to find a literature classic that had a graphic novel adaptation, taking into account that few literature classics have these kind of "reconstruction".

As there was not plenty of time to read the whole book, an extract from this novel was selected. In addition, choosing a smaller excerpt was a strategy to make the activity interesting for them to do. The piece chosen was from the moment dr. Victor Frankenstein locks himself in his laboratory to develop his experiment to the moment the scientist runs away from the Creature, which is already alive. (novel page 08-10; graphic novel page 22-28). Among many different moments and situations the book offers, this is the main point of the story in which the Creature comes to life. Therefore, in my personal opinion, as it presents new features when compared to regular books, students would like this part as well.

For one questionnaire, the extract from the story in novel format was inserted and the other questionnaire presented the same extract in graphic novel format. It is highly important to mention that the questions which followed the two different format texts were the same. The only difference was that each questionnaire presented one type of these texts.

\subsubsection{Closed Questions}

Immediately after the text, the questionnaire offers closed questions. These are called closed questions because they offer limited options to be chosen as answer, as yes/no questions or likert scales. 
Likert scale is named after its creator, Rensis Likert, who developed it in 1932. It is a psychological measurement used to gauge attitudes, values and opinions (MCLEOD, 2008). In likert scale measurement, the participants choose, among the options given, how they feel their answer is in the scale. Usually, the scales can be rated on a 1-to-5 or 1-to-7 agree or disagree response scale. In the case of this work, the likert scale consisted of 1-5 scale, which varies from "very - a little - neutral - a little - very" poles. The participant was supposed to choose the degree that best fit his/her opinion.

The aim of this paper was not only to discover students' opinion about each type of text, but also, and mainly, their emotions, how these texts made them feel. As Van Peer et al (2007:128-129) explain, "likert scales are used to test attitudes, not knowledge". For this reason, two tables were created to divide each of these aspects. The first table referred to emotions and feelings and the second table referred to students' opinion about the extract they received.

This presentation had to be done in three different days, one day in each class. On day one, the first group received the questionnaire with the graphic novel text; on day two, the second group answered the questions after reading the novel text; and on day three, the third group received both questionnaires, some students with the novel text and others with graphic novel format.

I informed them that they did not have to write their names, that the work was anonymous, emphasizing that their opinion and responses were the important aspects to my work. In addition, I explained that those questions were not a type of text comprehension test or any other school examination. I told them that those questions were about them (feelings) and about the text itself (their opinion). 
Interestingly, students, with no exception, were all curious and anxious to read the text they received. There were some few doubts about vocabulary but it was quickly explained and solved. Generally speaking, students read and answered the questions and no other doubts have emerged.

In order to conduct this analysis of students' answers, the semantic differential scale was used. This one, similar to the likert scale, asks participants to indicate to what extent they agree or disagree with a statement. However, semantic scale offers options that oppose each other, for instance, listing antonym pairs. This is a tool largely applied in questionnaires in which scales or levels are given as options to have a more reliable way to get the answer from the participants because they can express their views and opinions by selecting an option in the scale given (VAN PEER et al, 2007: 128).

It is important to mention that these words chosen were familiar to students of that age. Two tables were created: one related to feelings and emotions and a second one with adjectives related to text characteristics. For this, two dictionaries were used to find the opposite for each word, the Merriam-Webster dictionary and Oxford Dictionary, both online versions. 


\begin{tabular}{|c|c|}
\hline Curious $<>$ Indifferent & Pleasant <> Unpleasant \\
\hline Happy <> Sad & Easy $<>$ Difficult \\
\hline Anxious $<>$ Reluctant & Interesting <> Boring \\
\hline Surprised $<>$ Unsurprised & Long $<>$ Short \\
\hline Inspired $<>$ Discouraged & Formal $<>$ Informal \\
\hline $\begin{array}{c}\text { Courageous <> } \\
\text { Frightened }\end{array}$ & Touching <> Unmoving \\
\hline Relaxed $<>$ Upset & Engaging $<>$ Undesirable \\
\hline \multirow[t]{5}{*}{ Table 1} & Clear $<>$ Confusing \\
\hline & Intense $<>$ Light \\
\hline & $\begin{array}{l}\text { Informative <> } \\
\text { Uninformative }\end{array}$ \\
\hline & Stimulating $<>$ Tiresome \\
\hline & Table 2 \\
\hline
\end{tabular}

Figure 2: Variables - Adjectives

The adjectives were organized as follows: the positive aspects were placed on the left side of the table and its respective opposite on the right side.

In the case of this work, these scales were allocated between each pair of adjective. The tables below demonstrate how these lists were presented in the questionnaire. 


\begin{tabular}{|c|c|c|c|c|c|c|}
\hline & \multicolumn{5}{|c|}{ This text made me feel... } & \\
\hline & Very & A little & Neutral & A little & Very & \\
\hline Curious & & & & & & Indifferent \\
\hline Happy & & & & & & Sad \\
\hline Anxious & & & & & & Reluctant \\
\hline Surprised & & & & & & Unsurprised \\
\hline Inspired & & & & & & Discouraged \\
\hline Courageous & & & & & & Frightened \\
\hline Relaxed & & & & & & Upset \\
\hline
\end{tabular}

Table 1: Feelings and emotions

\begin{tabular}{|r|r|l|l|l|l|l|}
\cline { 2 - 5 } \multicolumn{1}{c|}{} & \multicolumn{5}{c|}{ I think this text is... } & \multicolumn{1}{c}{} \\
\cline { 2 - 5 } \multicolumn{1}{c|}{} & Very & A little & Neutral & A little & Very & \\
\hline pleasant & & & & & & unpleasant \\
\hline easy & & & & & & difficult \\
\hline interesting & & & & & & boring \\
\hline long & & & & & & short \\
\hline formal & & & & & & informal \\
\hline engaging & & & & & & unmoving \\
\hline clear & & & & & & undesirable \\
\hline intense & & & & & & light \\
\hline informative & & & & & & uninformative \\
\hline stimulating & & & & & & tiresome \\
\hline
\end{tabular}

Table 2: Students' opinion

The closed questions were analysed taking into consideration two different aspects. One refers to students' emotions and feelings, as the first table question reads 
'This text made me feel..."; the other refers to students' point of view, their own opinion about what they have read, as the second table question reads "I think this text is...".

In order to make a comparative analysis of the closed questions, SPSS, a statistical software (Statistical Package for the Social Sciences) version 21, was used.

The second method is related to open response questions, which were analysed differently, as students were free to write whatever they would like in their answers. As in the second table, in these open questions the students' opinion was the main aspect to be viewed.

For this purpose, it was necessary to organize the answers and create different categories to group students' responses according to their judgement about the text. The following categories were set in four blocks: Language issue (related to word meaning or grammar aspects), Plot/Story content (related to a fact or situation in the story), Characters/Places (any characters or setting that may have caught their attention), Emotions and Feelings (any part that may have caused different sensations on students).

\subsubsection{Open questions}

Following the closed questions, the foregrounded passages were obtained by means of open questions, which were added to the questionnaire with the intention of fully understanding what the students' thought about the text they read, and also to observe what they felt to be intense or different; something that drew their attention.

Differently from the closed questions, in which limited options were provided, in the open response questions, as they are discursive, students were free to write anything they wanted to, according to the extract they received, novel or graphic novel. In total, four categories were obtained from the answers to the open questions: 
language issue (related to word meaning or grammar aspect); plot /story content (related to the story content); characters and places; emotions and feelings (any passage or word that has caused a different sensation). These will be explained in detail in Section 4.3.

\subsection{Reading Preferences}

To obtain a profile of each student, two questions were presented. The first one checked if they liked reading and why, in case of yes or no answers. The second one was about their reading preferences. Some types of text were listed and students had to number them according to their personal preferences. In this case, 1 would be assigned for the text the student liked most and 10 for the type of text he/she liked the least. The types of texts listed there were: novel, magazine articles, biography, poetry, traditional literature, news, fairy tales, graphic novel, plays and cartoons.

\subsection{Context}

This research was developed in a private bilingual school in Rio de Janeiro. There, English is the only language used by teachers to teach all school subjects, from Arts to Mathematics. In addition, even in extra-curricular activities, as music and physical education classes, everything is taught by speaking English.

The number of students in each classroom is limited to 21 students, which makes it easier for the teacher to attend to students' needs and also for the student, who can concentrate more throughout the classes.

The teachers are free to use materials given by the school, along with technological resources, that are also available, as computers, smartboards and sound systems in all classrooms. 
The school also offers computer labs with the latest systems and equipment. The institution also motivates children to do other activities in its libraries. In this branch I work at, there are three libraries: one offers books for early year students, a second one for middle school classes and a third one makes materials available for senior school. There, not only books can be borrowed, but also comic books, magazines, graphic novels and DVD's. It is surely a pleasant place to study, as there are tables and comfortable chairs or, if the students prefer, there are cushions on the floor in case they want to read in a different place.

I decided to conduct this research at this specific context mainly because the school offers all these advantages. Participants already speak English fluently and it is the place I work at. I knew some of the students that participated in this research and also their teachers, and I think investigating my own context adds to my professional experience as a teacher.

It is important to mention that an authorization from the school was necessary in order to conduct this research.

\subsection{Participants}

The students who took part in this experiment were from three 5th grade groups. Their age average was between 9-11 years old and all of them spoke English fluently. In total, there were 60 students, 31 boys and 29 girls.

Most students that attended this school had been studying there since they were 2-3 years old. For this reason, the language itself represented no barrier for them to understand the subjects taught. Indeed, there were some foreign students, in the case of these groups, from 60 students only 10 children were not Brazilian, which obviously did not affect their participation in this research as their English level were all the same. 
Another aspect to be mentioned is that I was not their teacher. The teachers introduced me to these groups, explaining that they would help me to do a work for university. Obviously, all of them were very curious to know what I was doing there.

While talking to them, I explained that I was looking for a group of students that was clever, smart and intelligent to help me with my work. They soon felt they were very special because they were chosen.

\subsection{Methods of analysis}

The closed questions were analysed taking into consideration two different aspects. One refers to students' emotions and feelings, as the first table question reads 'This text made me feel..."; the other refers to students' point of view, their own opinion about what they have read, as the second table question reads "I think this text is...".

In order to make a comparative analysis of the closed questions, SPSS, a statistical software (Statistical Package for the Social Sciences) version 21, was used.

The second method is related to open response questions, which were analysed differently, as students were free to write whatever they would like in their answers. As in the second table, in these open questions the students' opinion was the main aspect to be viewed.

For this purpose, it was necessary to organize the answers and create different categories to group students' responses according to their judgement about the text. The following categories were set in four blocks: Language issue (related to word meaning or grammar aspects), Plot/Story content (related to a fact or situation in the story), Characters/Places (any characters or setting that may have caught their attention), Emotions and Feelings (any part that may have caused different sensations on students). 


\section{Results}

Analysing the first question that reads Do you like reading? Yes/No? Why?, not all students were able or could answer this question properly, as the table shows.

\begin{tabular}{|l|r|}
\hline & Boys and girls \\
\hline Yes + Justification & 36 \\
\hline No + Justification & 13 \\
\hline Yes +0 & 7 \\
\hline No +0 & 0 \\
\hline $0+0$ & 1 \\
\hline$>3$ students could not decide as they \\
have written yes and no. \\
\hline
\end{tabular}

Table 3: Participants' proximity to reading

Among all participants, 36 students said they liked reading and justified their answers; 13 said that they do not like reading and justified their responses. Some others answered but did not present a reason for this reply and only one did not answer. Leaving the justification blank may lead to the thinking that either participants were trying to do the activity briefly, or they could not explain why they like to read or not.

When it comes to the separate analysis of boys and girls, the number varied considerably. Among 31 girls, 27 said that they liked reading and 3 others stated they did not like reading, while in a group of 29 boys only 16 mentioned they liked reading and 10 others said they did not like it, as illustrated below: 


\begin{tabular}{|l|r|l|r|}
\hline Girls & & Boys & \\
\hline Yes & 27 & Yes & 16 \\
\hline No & 3 & No & 10 \\
\hline \multicolumn{3}{|l|}{} \\
\hline
\end{tabular}

Table 4: Comparative analysis - Boys/Girls

For both groups of students, who answered yes or no, their justifications were very interesting and some similarities could be found in many of these responses.

Students that mentioned they liked reading explained that this activity made them use their imagination when going through the story (Q.01. Q.06, Q.10, Q.20, Q.28). Interestingly, these students read the novel text. Moreover, some children highlighted the aspect of learning more words or things they did not know when reading a text, novel or graphic novel (Q.03. Q.07, Q.19, Q. 25, Q.37, Q.40, Q.41, Q.43, Q.48). From these two aspects, the majority of students that mentioned learning or imagination features were girls (12 girls and 2 boys).

Not different from that, other students stated that reading was fun $(\mathrm{Q} .03, \mathrm{Q} .05$, Q.23, Q.33, Q.41) and interesting (Q.14, Q18, Q.42, Q.45), when travelling or only for studying. Following the same pattern, some other readers raised the fact that reading gave them inspiration and made them discover new things (Q.11, Q.26) and places (Q.13, Q.53).

Some other aspects as feelings and happiness were also remembered. Two students who read novel text said that they felt something different when reading that, it seemed they were in the story (Q.02, Q.09). Another student mentioned that she felt happy when she read it (Q.46). Another student brought up an interesting point of view. According to him, reading brings imaginary things to life, to the real world (Q.54). 
However, not only positive aspects were raised. Obviously not all students considered reading as something interesting, or a bridge to learning new things. Some of them said they did not like reading mainly because they thought it was boring and tiresome and, according to them, something they had no patience to do. In this case, 10 students who indicated these factors as important when talking about reading, 7 were boys and 3 were girls (Q. 12, 16, 24, 30, 34, 35, 44, 49, 51, 60).

There were 4 students who were not sure about their answer. Two of them had written yes and no for the first question. One of them agreed that we learn when we read, but it is a waste of time doing so (Q.25). The other one was indecisive about what to say, mentioning that sometimes reading is boring, but it is nice sometimes (Q.24).

It can be concluded that, for this specific group, girls showed more interest in reading than boys, regardless of the type of text because this question was not related to the text they received, but to texts in general.

Still building the readers' preference profile, the second query considered which types of texts students preferred to read. It was observed that among the options offered, cartoons and novels were number one in preference. Following these, the second type of text chosen as their favourite was plays, and the third in the list were magazine articles and fairy tales. Graphic novel, which is one of the texts used in this research, was not a favourite one and it was chosen by most students as number 8 in the scale of preference from 1 to 10 .

For the analysis of the closed questions, ANOVA test was run, and it made it possible to check if the two groups (graphic novel and novel) had different (or similar) reactions to the text. This test enabled us to compare the means of answers to each one of the scales of the two groups of participants. Table 5 displays the means of answers of the groups in relation to each variable. 


\begin{tabular}{|c|c|c|c|}
\hline & & Novel & Graphic Novel \\
\hline \multirow{7}{*}{ 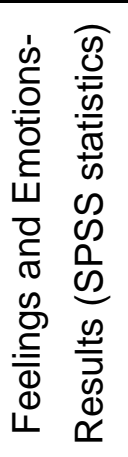 } & Curious & 1.65 & 1.84 \\
\hline & Happy & 2.89 & 3.10 \\
\hline & Anxious & 2.04 & 2.33 \\
\hline & Surprised & 2.38 & 2.30 \\
\hline & Inspired & 2.59 & 2.79 \\
\hline & Courageous & 2.70 & 2.77 \\
\hline & Relaxed & 2.52 & 2.96 \\
\hline \multirow{11}{*}{ 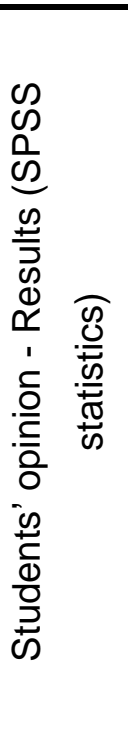 } & Pleasant & 2.32 & 2.30 \\
\hline & Easy & 1.96 & 1.54 \\
\hline & Interesting & 1.67 & 1.72 \\
\hline & Short & 3.04 & 4.31 \\
\hline & Formal & 3.12 & 3.11 \\
\hline & Touching & 2.93 & 3.07 \\
\hline & Engaging & 2.57 & 2.71 \\
\hline & Clear & 1.68 & 2.07 \\
\hline & Intense & 2.63 & 2.39 \\
\hline & Informative & 2.57 & 3.00 \\
\hline & Stimulating & 2.58 & 2.64 \\
\hline
\end{tabular}

Table 5: Comparative analysis - Variables

It is important to mention that a brief explanation to students was given on how they would choose their option using the likert scale. Some examples were given, using the same tables, to show them they had to choose only one option among the ones presented in each scale. I had to show them that these scales were like levels to measure their perceptions.

In order to better understand the results, let us consider the first adjective as an example. The means of answers of the participants who read the novel to the curious / indifferent scale is 1.65 , that is, most participants of this group evaluated the text as either very curious (the first point of the 5-point scale) or a little curious (the second point of the 5-point scale). Participants who read the graphic novel had a rather similar 
result, as the means of their answers is 1.84 , which is also between the first and the second point of the 5-point scale. It is then possible to say that both groups of participants stated that they felt curious when reading the text, with no significant difference between the groups.

There was only one significant difference between the groups: in relation to the variable "short". It means that the graphic novel readers evaluated this text as being short, while the novel readers considered their text as neutral in terms of size. Therefore, the comparative analysis showed that the way readers felt while reading both texts, as well as the way they evaluated the texts were similar - with the only difference in relation to size. The following sections aim at detailing the results of the research.

\subsection{Readers' reaction to the texts}

This section has the objective of presenting the readers' reactions to the graphic novel and the novel. Figure 3 shows the average of answers of the two groups in each scale: the blue ball represents the average of answers of the novel group, while the red ball of the graphic novel one. The closer the value is to 1 , the closer it is to the adjective on the left side of the scale. When the answers are closer to 3 , it means that the participants marked the middle of the scale most often, being more "neutral" in relation to the variable. 


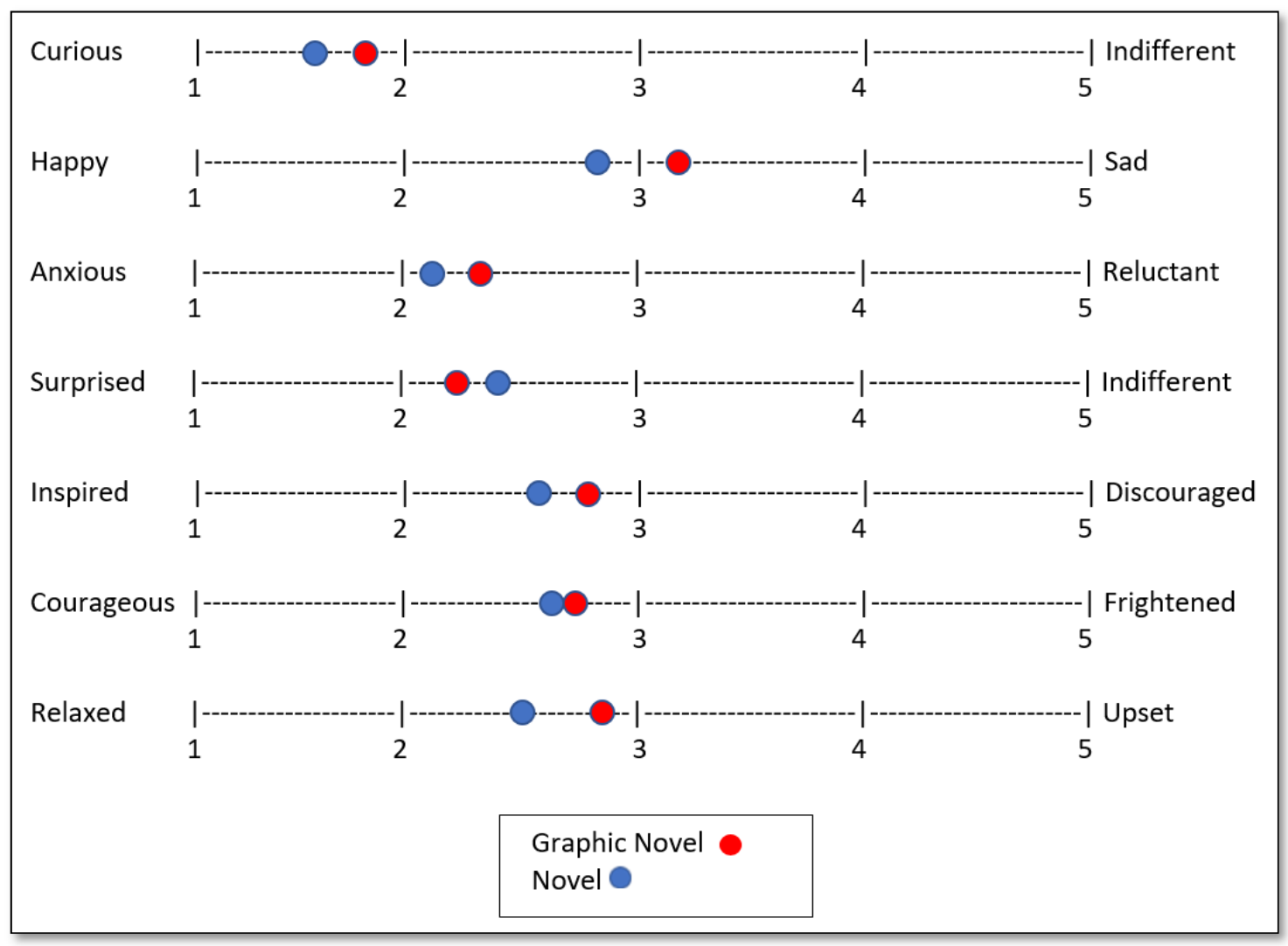

Figure 3: Readers' feelings

Figure 3 shows that students who read the graphic novel and the ones who read the novel seem to have similar reactions. Both of them felt curious, anxious, and surprised. They also felt inspired, courageous and relaxed, but in a lesser degree, as the answers tended to be closer to the middle of the scale. In relation to the adjectives "happy / sad", both groups tended to the neutrality, but there is a slight difference, as the novel participants had a more positive reaction than the graphic novel ones. However, there was no significant difference between the groups in any of these variables.

Another aspect that must be considered is the fact that novel (the blue ball) is most frequently more positive than graphic novel (the red ball). It means that the novel group had more positive feelings while reading than the graphic novel one. The only exception is in relation to "surprised / indifferent", in which graphic novel participants 
felt more surprised than the other group. Although the statistics test showed no significant differences, these results may indicate a slight tendency for difference between readers' reactions.

4.2 Readers' evaluation of the texts

The second aspect that was analysed refers to the way students evaluated the texts they read. Figure 4 displays these results.

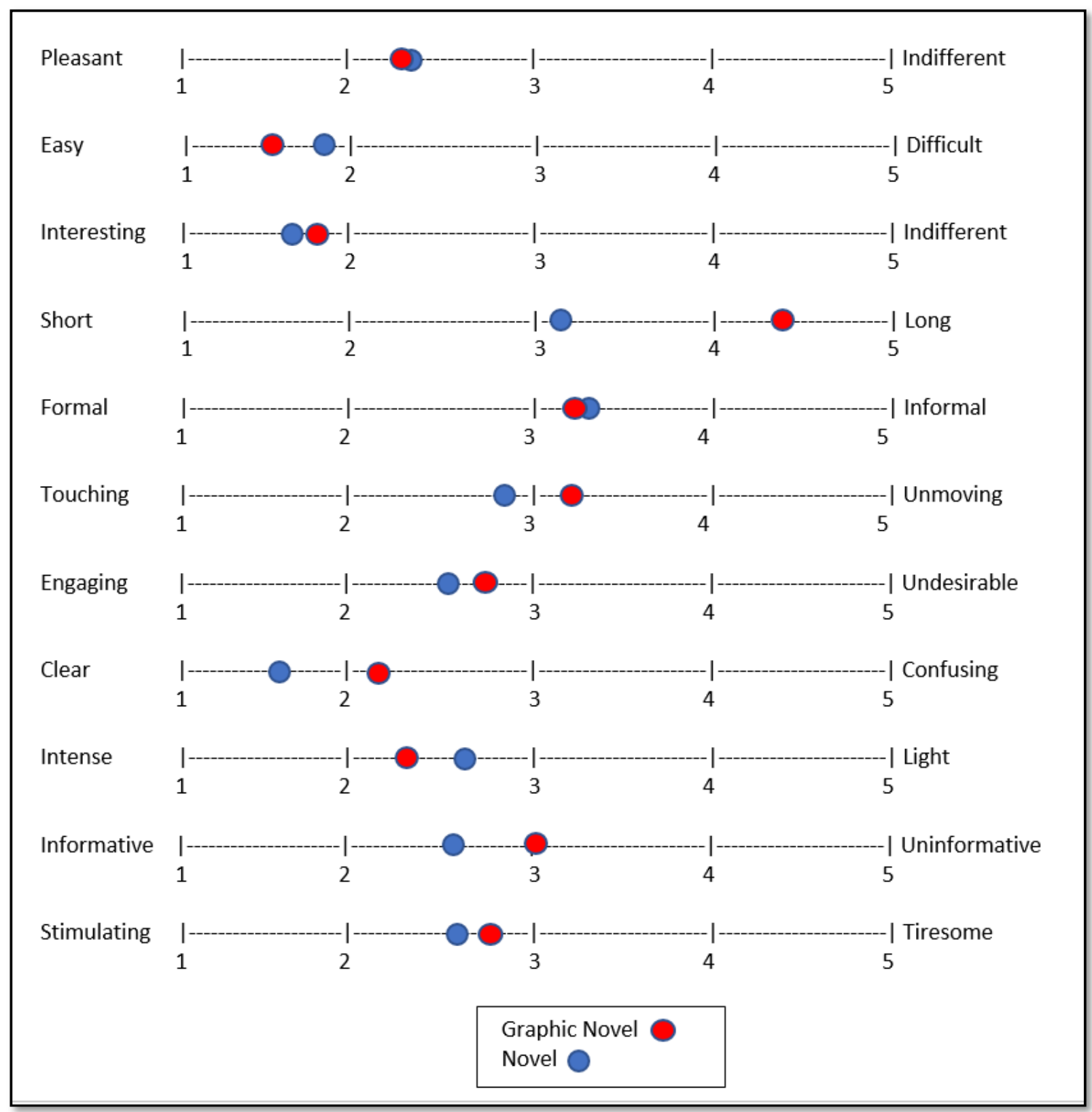

Figure 4: Readers' evaluation of texts 
It is possible to see in Figure 4 that, again, both groups had similar answers. Both groups considered the text pleasant, easy, interesting and clear. Some answers were closer to the middle of the scale, which made us consider that they tended to be neutral in relation to the adjectives: "formal / informal", "touching / unmoving", "engaging / undesirable", "intense / light", "informative / uninformative" and "stimulating / tiresome". Some slight differences can be noticed, as the novel group seemed to have more positive answers than the novel group in relation to the variables: "touching / unmoving", "engaging / undesirable", "clear / confusing", "informative / uninformative" and "stimulating / tiresome". The graphic novel group had slight more positive answers in relation to the variables "intense / light" and "easy / difficult".

The only difference between the groups was in relation to the pair of adjectives "short / long". The statistic test proved a significant difference between the groups in relation to this variable. The group that read the novel format thought the text was neither long or short (3.04), while the group that read the graphic novel format evaluated the text as being quite long (4.31). A possible reason to explain this difference is the fact that the graphic novel questionnaire was 8-page long (see Appendix B), due to the images, and participants who read this version might have had the feeling it was longer.

\subsection{Striking passages}

While reading the answers to the open questions of the questionnaire, to be more precise, the ones that asked them about the most striking passages in their opinion, it was possible to see that they tended to highlight some parts based on the same principles. Their choice and the way they justified it were categorized in 4 main 
aspects, which are: (a) language issue; (b) plot or story content; (c) characters and places; and (d) feelings / emotions

The first group, which refers to the language issue, included answers that commented on a specific word, or any grammar aspect. In these groups, some answers were similar or even the same. The word "shivering" was chosen three times (found in Q. 03, Q. 05 and Q. 21) as well as the word "fear" (Q.13). The students also mentioned the word "wildest" (Q.55). Another word that drew students' attention was "horror" (Q. 41, Q. 53 and Q. 60). It was highlighted by some participants that they chose these words as the most striking passages specially because they were not so sure about the meaning of them, which demonstrated that these words might have been obstacles to their reading comprehension.

The second group refers to answers that were focused on the plot or story content. Phrases and sentences caught students' attention, as "it was alive" (Q. 04, Q. 06, Q. 25, Q. 26), "spark of electricity” (Q. 18), "and I had the wildest dreams" (Q. 35) and "building bodies" (Q. 01). In addition, some moments of the story were also mentioned by the students. Some of them highlighted some actions in the story, like the moment the monster wakes up and stands in front of Victor (Q. 08), when Victor dreamt of kissing Elizabeth and she turned into the monster (Q. 51), and even the monster's eyes description (Q. 19).

The third group offered answers that showed that they valued more the characters or places that have caught the readers' attention for a specific reason. The names Frankenstein (Q. 44) and Victor (Q. 11) were mentioned, as well as Ingolstadt (Q. 45) and the monster itself (Q. 54).

The fourth group refers to passages or words that caused different feelings while reading, according to students' justifications. The passage "It was alive" was 
chosen because it was taken as an intense moment of the story (Q. 04). Or the moment when Victor wakes up and the monster was in front of him, because this was terrifying (Q. 08). Also, the moment when Victor was scared and could not sleep was considered as scary and the story's best scene (Q.15). Some words caused also different feelings, as in "lifeless" that made a student feel afraid of the monster at the moment he gets life (Q. 29). One student highlighted that the story made her feel as if she were part of the story (Q. 20), which makes us think that she was into the activity and felt it in a realistic way. 


\section{Discussion}

The results of this work are rather surprising. From the beginning of the work, I had in mind - and was almost sure - that graphic novels would stand out as students' preference and that they would be the perfect tool for stimulating students into reading. However, the study showed that actually both formats are considered interesting, pleasant and students were very curious about them.

While doing my search for similar works which had graphic novels as their object of study, many of them showed positive results: that the use of more visual texts in pedagogical contexts were indeed helpful and solved students' reading issues (NEWKIRK, 2006); other works highlighted that these types of texts were more engaging than the regular novel books (KRASHEN, 1996); and also that by the reading of images and text, students construct meaning and become actors of their own learning process (MANNO, 2014). As many works brought positive results when using graphic novels in classroom, I thought I would have a similar result or, at least, students would show preference for one or the other.

However, there were some authors that did not share the same point of view. Differently from the previous ones, these authors mention that the teachers hesitate in using comics in classroom due to the language these texts present: poor vocabulary offered. They also state that reading these types of text do not challenge students in developing their own view of that story (LÓPEZ-ROBERTSON et al, 2011).

The results in this paper show that there were not significant differences when using these two types of texts in pedagogical contexts, which was not anticipated. In fact, there was a difference considering the length of the texts: the graphic novel group evaluated the text as longer than the novel group. One possible reason for that is that the text in graphic novel format presented more pages than the novel extract. I 
anticipated that the graphic novel would offer readers a faster experience because of the images. I thought that the graphic novel would offer a Gestalt vision, i.e., visual perception and retention in the memory would be faster than the view constructed when reading a text with no images. However, participants did not react this way.

Considering the level of difficulty, the research also showed a little difference in responses between the groups. Maybe the graphic novel was considered easier than the novel because students did not take much time to read it and there was no effort to construct an understanding of that extract.

Although the graphic novel was considered easier to read than the novel, it was also evaluated as more confusing than the latter, which differs from the findings in the literature. As graphic novels present lots of images in each scene, it might have been confusing to understand what was happening in that section.

When it comes to getting information from that story, the novel provided more information than the graphic novel, according to their perception. As the reading of the novel format was longer and slowly carried out, they acquired and retained more details about the story.

In the qualitative part, considering the open questions, another aspect that caught my attention was related to imagination. As graphic novels present many images, there might have been little space for imagination. And for some works, the imagination is key to see the author's vision of a character or place. In the case of this research, some students preferred reading the novel, and when questioned why they preferred that type of text, they said that they can use their imagination, they create their own character and settings in their minds by reading the same description. In the graphic novel it is not possible, as they are not given the chance to create it, as the drawings are already there. This is explained in the theory of transportation (Green \& 
Brock, 2002) which mentions that reading transports the reader into the world of narrative, involving the reader with the characters of the story.

This is an aspect I have never thought about and I was really surprised. That may be the reason why the novel was also considered more touching and stimulating than the graphic novel.

There was no difference that could state that graphic novels are better or cause any different reaction in students. Actually, graphic novels did not catch the students' attention as I thought they would. In contrast, it showed a completely different result: although they are visually different, there was not a significant preference between the two. 


\section{Conclusion}

The results obtained in this study may lead to some reflection. Sometimes what we think students would hate reading, they actually love to read. It may also occur that they have never had contact with other types of texts, in different formats and may react in unexpected ways.

The results from this study contradict many studies in the literature, as well as my own view about using graphic novels in the classroom. Indeed, they are different types of texts and obviously are visually attractive, but these characteristics do not guarantee students' pleasure in reading. We may conclude that teachers' assumptions may not correspond to students' preferences. That is why teachers must establish a relationship with their students to check their preferences and be open to listen to them in order to meet pedagogical goals.

Further studies are needed for more specific and detailed information about the use of graphic novels in classroom. The story presented was interesting for these students maybe because the theme was appealing to them, as they had just begun to get into the world of science fiction. Perhaps if another type of story or a different classic were used, obviously presenting another theme, as a novel by Jane Austen, we might expect different results. Or even if this research was developed in completely different contexts, as other schools, or with older participants, results may be different. All this remain as hypotheses that need to be checked.

We hope that this research has pointed out the relevance of investigating students' reading interests so as to allow teachers to tune their teaching practices to students' interests. Reading is an important skill which is developed only through practice and all efforts should be expended so as to understand what actually may stimulate students. 


\section{References}

BARRS, M. Knowing by Becoming: developments in writing and art. In: MECK, M.; MILLER, J. (Eds.). Changing English: essays for Harold Rosen. London: Heinnmann, 1986. p.71-86.

BIBIANO, B. $40 \%$ dos alunos concluem o ensino fundamental sem saber interpretar textos. Available at: <http://veja.abril.com.br/educacao/40-dos-alunos-concluem-oensino-fundamental-sem-saber-interpretar-textos/>. Accessed on: July 25, 2017.

BLAKE, C. Defining Multiple Literacies: The expression of learning in many formats. Concordia University. Retrieved from: http://online.cune.edu/defining-multipleliteracies/ (Accessed on Nov 16,2016)

BRENNER, R. Guide to using graphic novels with children and teens. 2015. Available at: $\quad$ <https://www.scholastic.com/content/dam/teachers/lesson-plans/migratedfeatured-files/guide_to_using_graphic_novels_new_2015_0.pdf>. Accessed on: Nov, 11, 2016

CARVALHO, J. Trabalhando com quadrinhos em sala de aula. 2009. Available at: <http://www.educacaopublica.rj.gov.br/suavoz/0116.html>. Accessed on: July 25, 2017.

CHILDS, P.; FOWLER, R. Routledge Dictionary of Literary Terms. 2006. Available at: < https://www.uv.es/fores/The_Routledge_Dictionary_of_Literary_Terms.pdf> . Accessed on: March 08, 2017.

DYSON, A.H. Social Worlds of Children Learning to Write in an Urban Primary School. New York: Teachers College Press, 1993.

FEIJO, M. Quadrinhos em ação: Um século de história. São Paulo: Editora Moderna, 1997.

FISH, S. Is There A Text in This Class?. Cambridge: Harvard University Press, 1980. 
FISH, S. Literature in the reader: Affective Stylistics. New Literary History 2, no 1.1970. p. $70-100$.

Available at:

<http://www.philol.msu.ru/ discours/images/stories/article2.pdf>. Accessed on: Jan $31,2017$.

FRANCIS, P. Frankenstein: A horror classic. London: Evans Brothers Limited, 2007 FREIRE, Maria Angélica; Mendonça, Rosa Helena. Práticas de leitura e escrita. Brasília: Ministério da Educação, 2006.

GARDNER, H. Frames of Mind: The Theory of Multiple Intelligences. New York, NY: Basic Books. 10 ${ }^{\text {th }}$ edition, 2011.

GORMAN, M. Getting Graphic! Using graphic novels to promote literacy with preteens and teens. Worthington, Ohio: Linworth Pub, 2003

GREEN, M; BROCK, T. C. The role of transportation in the persuasiveness of public narratives. Journal of Personality and Social Psychology, Vol. 79, nํ5, 2000. pp. 701721.

HAINES, J. Why teach with comics?. 2012. Available at:

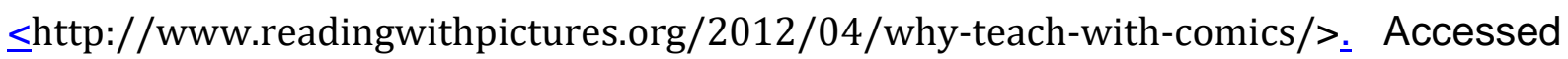
on: May 25, 2016.

HAKEMULDER, J; VAN PEER, W. Foregrounding. Encyclopaedia of Language \& Linguistics. Vol. 4, pp. 546-550. 2006.

HASSET, D.D.; SCHIEBLE, M.B. Finding space and time for the visual in K-12 literary instruction. The English Journal, 97 (1), 62-68. 2007.

HAUGEN, D.M. Comic Books: Examining pop culture. Detroit: Greenhaven Publishing, 2005. 
HOLLAND, N. Unity Identity Text Self. In: TOMPKINS, J. P. Tompkins. ReaderResponse Criticism: From Formalism to Post-Structuralism. Baltimore and London: The Johns Hopkins University Press., 1980. pp.118-33

ISER, W. The Implied Reader: Patterns of Communication in Prose Fiction from Bunyan to Beckett. Baltimore: Johns Hopkins University Press, 1974.

JEWITT, C.; KRESS, G. Multimodal Literacy. New York: Peter Lang, 2003.

JUNIOR, G. Quem disse que os quadrinhos são inimigos dos livros? . Revista Pesquisa $\quad$ FAPESP. $2009 . \quad$ Retrieved from: <http://revistapesquisa.fapesp.br/2009/07/01/quem-disseque-os-quadrinhos-saoinimigos-dos-livros/>. Accessed on: Jan 03, 2017.

KRASHEN, S. The Power of Reading. Englewood: Libraries Unlimited, Inc., 1993.

KRESS, G.; VAN LEEUWEN, T. Reading images: The grammar of visual design. New York, NY: Routledge, 1996.

LAPP, D.; FISHER, D. Handbook of Research on teaching the English language arts. New York, NY. Routledge. $3^{\text {rd }}$ edition, 2011.

LEECH. G.N. "This bread I break "- language and interpretation. In: FREEMAN, D.C. (Ed). . New York: Holt, Rinehart \& Winston, 1970. p. 119-128.

LENTE, F.V.; DUNLAVEY, R.V. The Comic Book History of Comics. CA, United States. IDW Publishing, 2012.

LÓPEZ-ROBERTSON, J; HARTMAN, A.; JUDY, J.; REEVES, L. To be or not to be: Graphic Novels in the classroom? Retrieved from: <http://wowlit.org/blog/2011/03/28/to-be-or-not-to-be-graphic-novels-in-theclassroom/>. Accessed on: Nov 16, 2015.

LUNDY, Kathleen Gould. Teaching fairly in an unfair world. Ontario: Pembroke Publishers, 2008. 
MANNO, M. Comics in the classroom: Why comics?. 2014. Retrieved from: <https://teach.com/blog/why-comics/>. Accessed on: Nov 16, 2015.

MCLEOD, S. A. Likert Scale, 2008. Available at: swww.simplypsychology.org/likertscale.html>. Accessed on: Sep 2, 2017.

MCQUILLAN, J. The Literary Crisis: False Claims, Real Solutions. Portsmouth: Heinnmann, 1998.

MIALL, D. S.; KUIKEN, D. Shifting perspectives: Readers' feelings and literary response. 1998. Available at: <https://sites.ualberta.ca/ dmiall/reading/index.htm> Accessed on: Jan 31, 2017.

MILLER, J. J. Comics and Graphic novels sales top $\$ 1$ billion in 2015. Available at: <http://blog.comichron.com/2016/07/comics-and-graphic-novel-sales-top-1.html>. Accessed on: Feb 21, 2017.

MORRISON, T.G.; BRYAN, G.; CHILCOAT, G. W. Using student-generated comic books in the classroom. Journal of Adolescent \& Adult Literacy, 45(8), 2002. p. 758767

MUKAROVSKY, J. 'Standard language and poetic language. In: FREEMAN, D. C. (Ed). Linguistics and Literary Style. Massachusetts: H.R.W, 1970. p. 41-53.

NEWKIRK, T. Media and Literacy: What's good?. Educational Leadership. P. 62-66. 2006.

Available at:

https://isu468research.wikispaces.com/file/view/Media+\%26+Literacy+Newkirk.pdf. Accessed on: Mar 18, 2016.

ROSENBLATT, L. M. The Reader, The Text, The Poem: The Transactional Theory of the Literary Work. Carbondale, IL: Southern Illinois University Press, 1978.

SANTOS, Mariana Oliveira; GANZAROLLI, Maria Emilia;. Histórias em quadrinhos: formando leitores. TransInformação. Campinas, 23(1) 63-75, jan/abr, 2011. 
SHELLEY, M. Frankenstein: 1818 text. New York, NY: OUP, 2008.

SHELLEY, M. Frankenstein: The ELT Graphic Novel. London: Heinle ELT, 2009.

SHKLOVSKY, V. Art as technique. In L. T. Lemon and M. J. Reis, trans., Russian formalist criticism: Four essays (pp. 3-24). Lincoln, NE: University of Nebraska Press. 1965

SOARES, M. V. Por que nossos alunos não gostam de ler?. 2015. Available at: shttp://educacaopublica.cederj.edu.br/revista/artigos/por-que-nossos-alunos-naogostam-de-ler $\geq$. Accessed on: July 25, 2017.

THOMAS, P. L. Adventures with text and beyond. English Journal, 102(2), Colorado, US. 2013. p. 129-133

TRELEASE, J. Read-Aloud Handbook. New York. Penguin Books. 5th edition, 2001. VAN PEER, W.; HAKEMULDER, F.; ZYNGIER, S. Muses and Measures: Empirical Research Methods for the Humanities. Cambridge: Cambridge Scholars Publishing, 2007.

VYGOSTKY, L. S. Mind in Society. Cambridge, MA: Harvard University Press, 1978. WERTHAM, F. Seduction of the Innocent. Ed. Holt, Rinehart \& Winston. 1954.

Relatório anual de resultados 2014. Instituto Ayrton Senna. (p. 15-19). Available at: <http://www.institutoayrtonsenna.org.br/content/dam/institutoayrtonsenna/docume ntos/relat\%C3\%B3rios-anuais/Instituto-Ayrton-Senna-Relatorio-Anual-de-Resultados2014.pdf.pdf>. Accessed on: March 08, 2017. 


\section{Appendices}

Appendix A: Questionnaire - Novel

Appendix B: Questionnaire - Graphic Novel

Appendix C: Open questions - Students' answers 


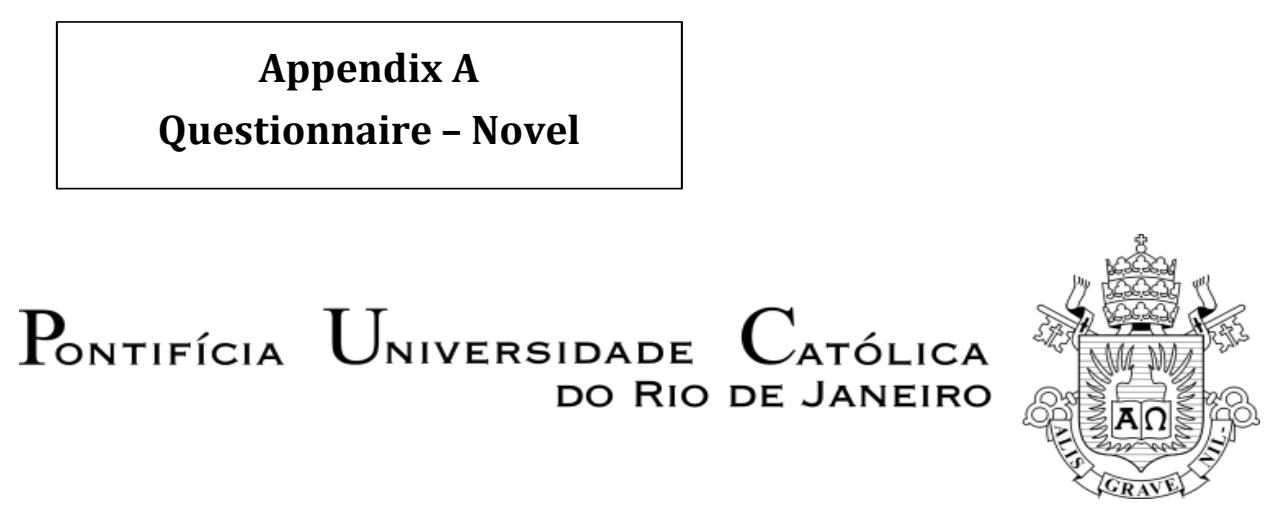

This questionnaire is part of a research about Brazilian students reading in English. It should take about 15 minutes to answer it. Remember, there is no right or wrong answers, it is your opinion that is important. This is an anonymous questionnaire, so your identity will be preserved. We thank you for your collaboration.

\section{Read the following text:}

You will be amazed when I tell you what this work was; but you must believe me. For two years, I had been building a human body - a body that I would bring to life. Yes, I, Victor Frankenstein, would put the spark of electricity into a lifeless body. And it would live!

At last, at one o'clock on a dreary November night, I finished building my human creature. Rain lashed against the windows and my candle had almost gone out. In the flickering light, he lay lifeless at my feet. He was about eight feet tall, too big I know now; but it was easier to fit together big body parts.

I could hardly believe what I was doing. This lifeless creature at my feet would look upon me as its creator. "Now! Do it now"'” I muttered to myself.

Trembling with anxiety, I picked up my instrument and sent a spark of electricity through his body. I waited, hardly able to breathe.

Suddenly, the creature opened its dull yellow eyes, took a deep breath and moved its arms and legs. It was alive! This should have been my greatest moment of 
happiness. But no" now he was alive in front of me, I was filled with despair. What had I done?

I forced myself to look at the creature I had worked so hard to make. I was horrified by its shrivelled, yellow skin, by its veins and arteries, by its straight black lips and by its watery, white eyes.

The beauty of the dream vanished. I was disgusted.

I ran to my bedroom and tried to sleep. I had terrible dreams until I awoke, suddenly shivering with fear. The miserable monster was standing in front of me, lit up by the yellow moon. His eyes, if you could call them eyes, were fixed on me. His jaws opened and a grin wrinkled his cheeks. He tried to speak as he put out his hand to me.

Terrified, I ran out into the street and hid. And all the time, I dreaded to see the dead body that I had brought to life.

Now, please mark how you reacted to the text. Please make sure to place only ONE tick for EACH line of the questionnaire.

\begin{tabular}{|c|c|c|c|c|c|c|}
\hline & \multicolumn{5}{|c|}{ This text made me feel... } & \\
\hline & Very & A little & Neutral & A little & Very & \\
\hline Curious & & & & & & Indifferent \\
\hline Happy & & & & & & Sad \\
\hline Anxious & & & & & & Reluctant \\
\hline Surprised & & & & & & Unsurprised \\
\hline Inspired & & & & & & Discouraged \\
\hline Courageous & & & & & & Frightened \\
\hline Relaxed & & & & & & Upset \\
\hline
\end{tabular}




\begin{tabular}{|c|c|c|c|c|c|c|}
\hline & \multicolumn{5}{|c|}{ I think this text is... } & \\
\hline & Very & A little & Neutral & A little & Very & \\
\hline pleasant & & & & & & unpleasant \\
\hline easy & & & & & & difficult \\
\hline interesting & & & & & & boring \\
\hline long & & & & & & short \\
\hline formal & & & & & & informal \\
\hline touching & & & & & & unmoving \\
\hline engaging & & & & & & undesirable \\
\hline clear & & & & & & confusing \\
\hline intense & & & & & & light \\
\hline informative & & & & & & uninformative \\
\hline stimulating & & & & & & tiresome \\
\hline
\end{tabular}

What word or passage has drawn your attention in the text?

Explain why you have chosen the word or the passage above.

Do you like reading? ( ) Yes （ ) No

Why (not)?

If you could choose, what type of books or texts would you like to read at school? Place them in order ( 1 to 10 ) of preference, 1 being the one you would like to read the most, that is, your FIRST CHOICE, and 10 the one you would like to read the least: 
( ) Novels

( ) Magazine articles

( ) Biography

( ) Poetry

( ) Traditional Literature

\section{About you}

Age:

Nationality:

Class:

Sex:

Boy

Study English since (age):
( ) News

( ) Fairy Tales

( ) Graphic Novels

( ) Plays

( ) Cartoons

\section{chras}




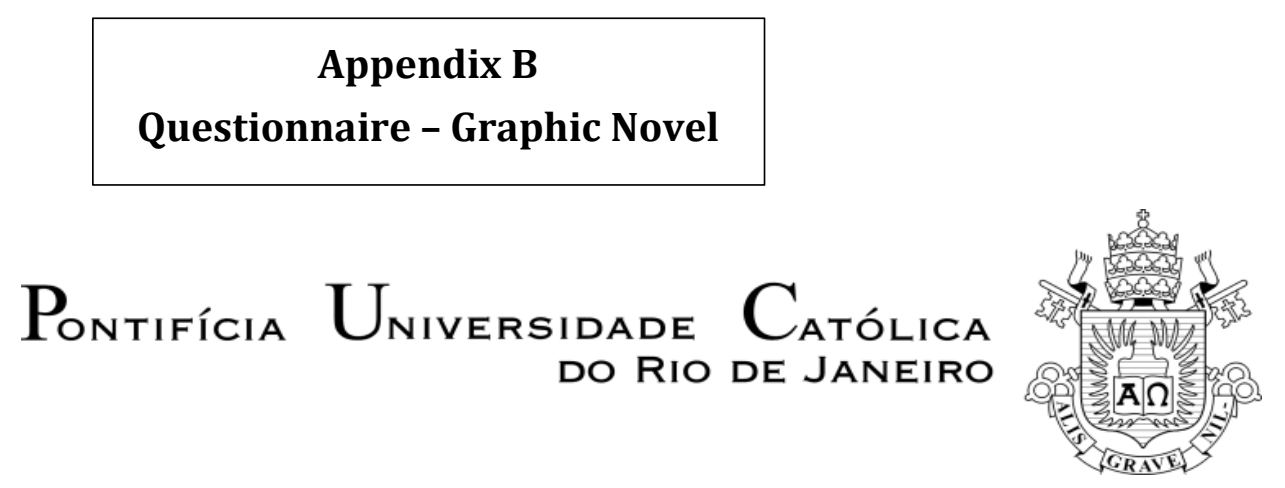

This questionnaire is part of a research about Brazilian students reading in English. It should take about 15 minutes to answer it. Remember, there is no right or wrong answers, it is your opinion that is important. This is an anonymous questionnaire, so your identity will be preserved. We thank you for your collaboration.

* Read the following passage: 


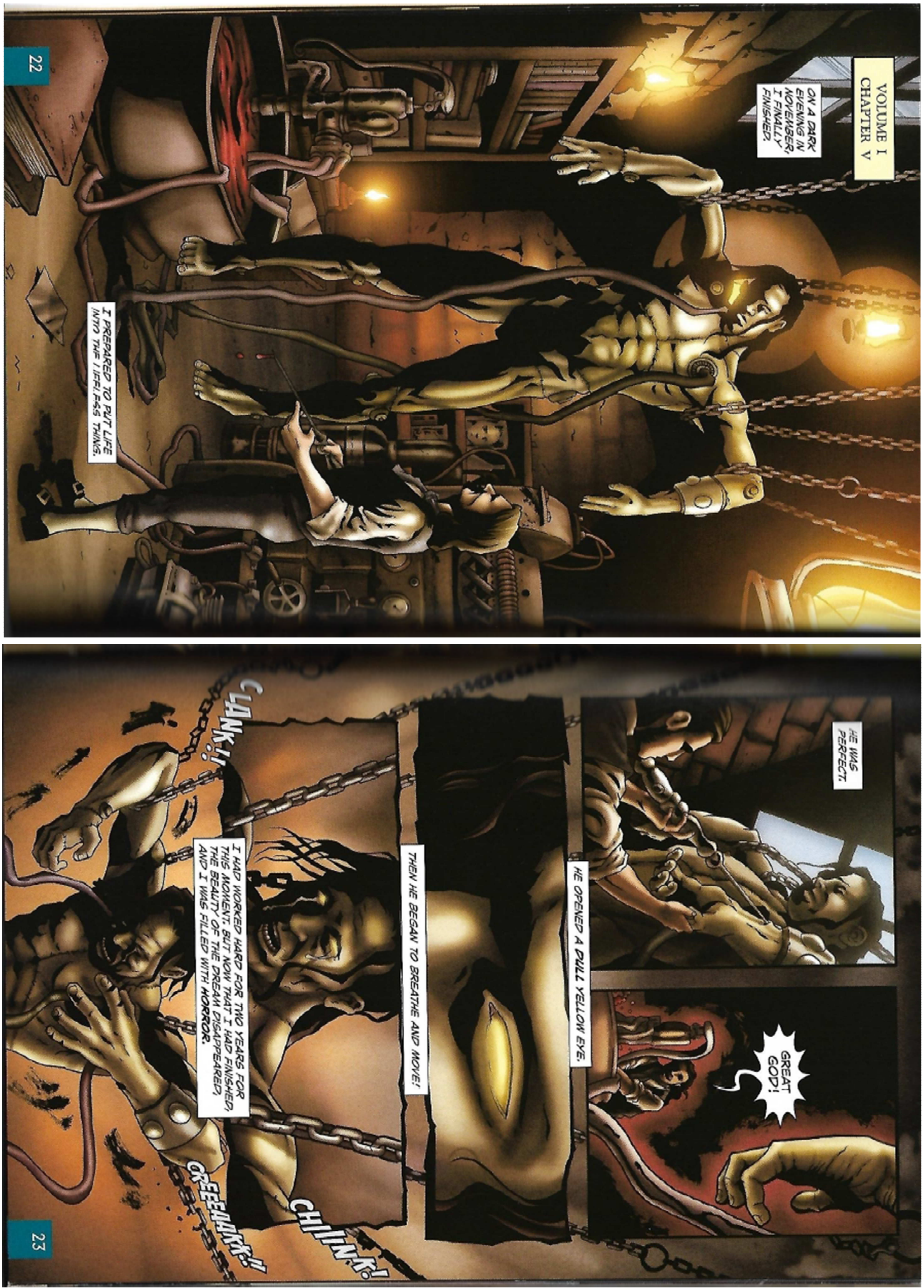




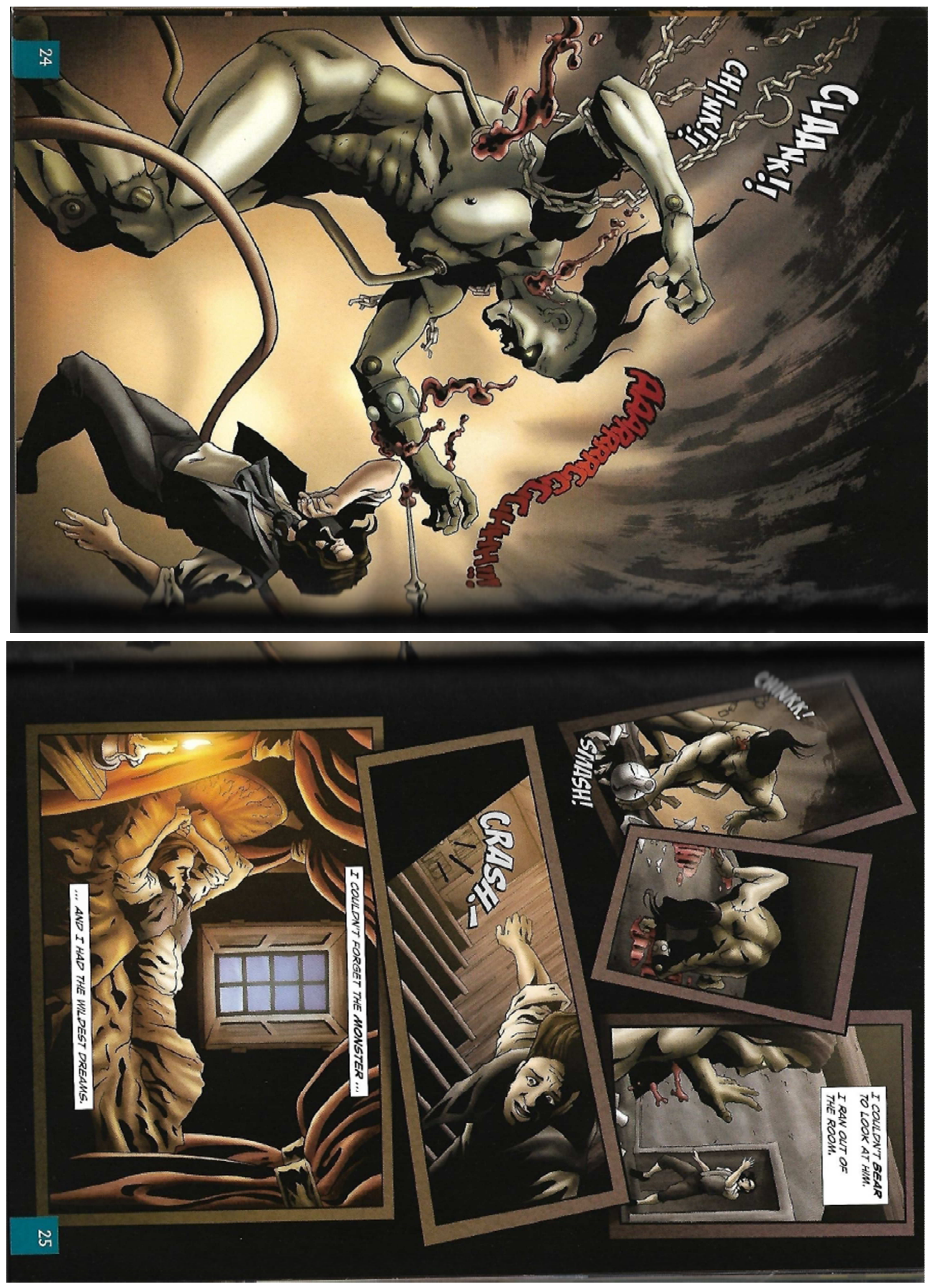


N

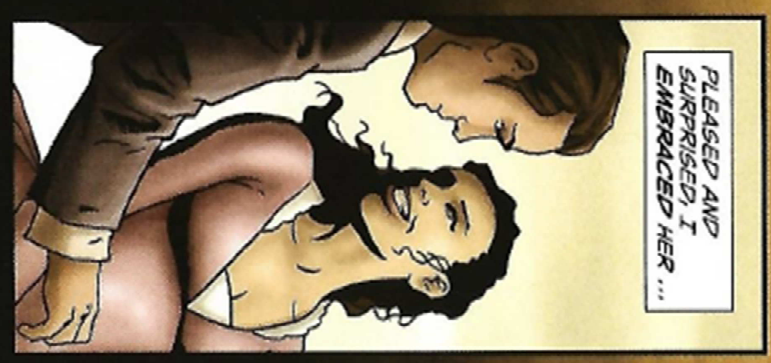

3
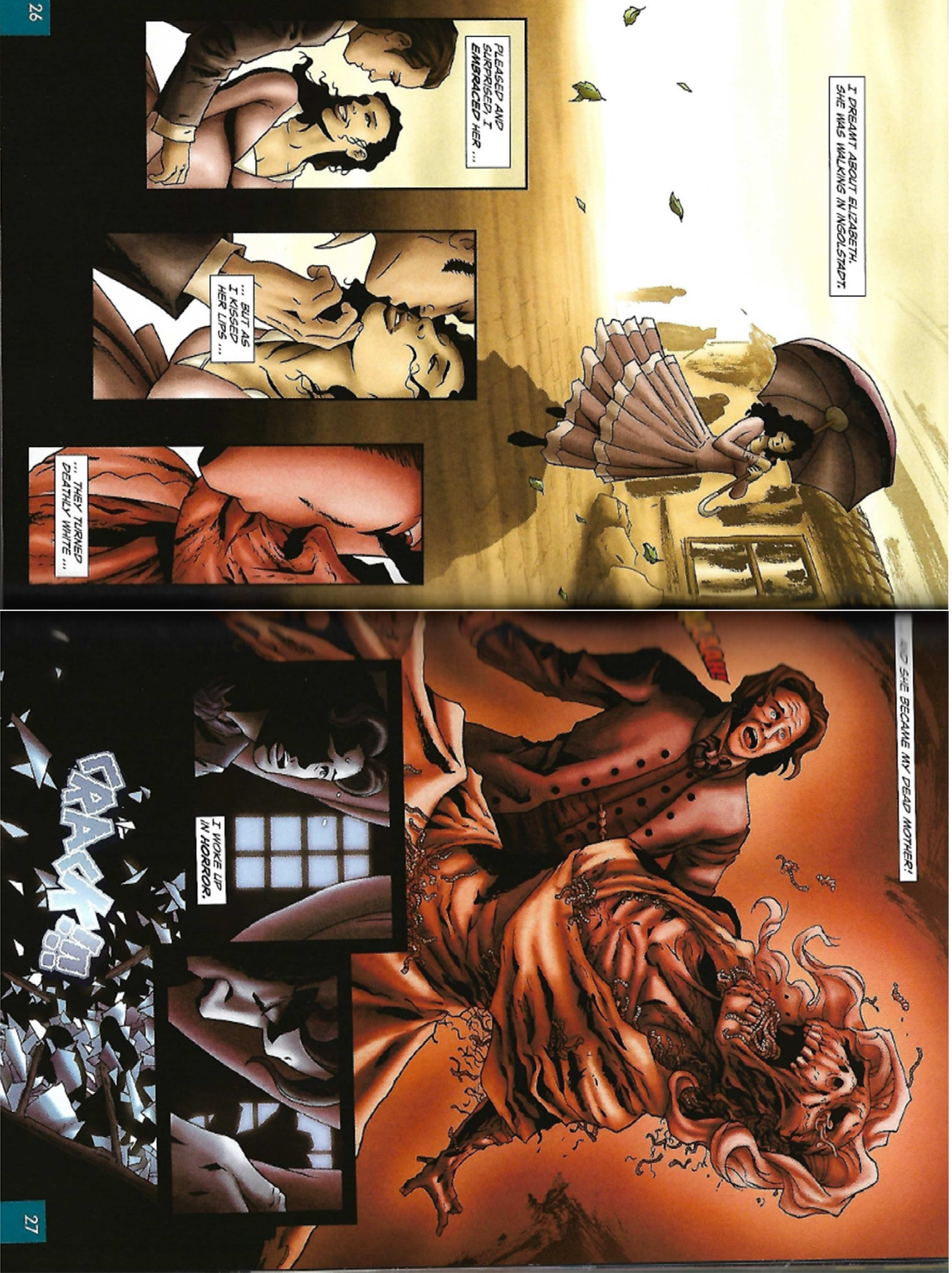


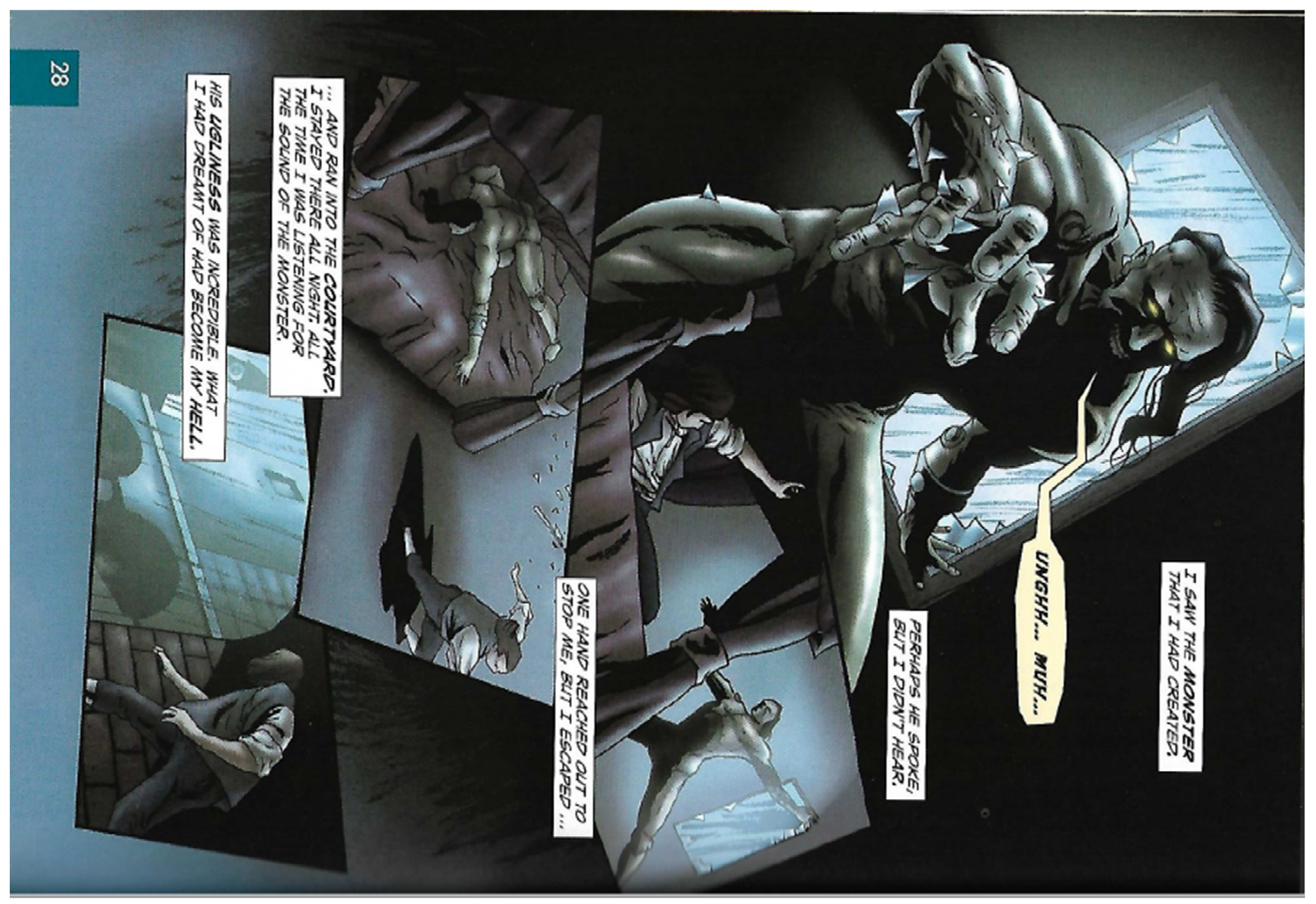


* Now, please mark how you reacted to the text. Please make sure to place only ONE tick for EACH line of the questionnaire.

\begin{tabular}{|c|c|c|c|c|c|c|}
\hline & \multicolumn{5}{|c|}{ This text made me feel... } & \\
\hline & Very & A little & Neutral & A little & Very & \\
\hline Curious & & & & & & Indifferent \\
\hline Happy & & & & & & Sad \\
\hline Anxious & & & & & & Reluctant \\
\hline Surprised & & & & & & Unsurprised \\
\hline Inspired & & & & & & Discouraged \\
\hline Courageous & & & & & & Frightened \\
\hline Relaxed & & & & & & Upset \\
\hline
\end{tabular}

\begin{tabular}{|c|c|c|c|c|c|c|}
\hline & \multicolumn{5}{|c|}{ I think this text is... } & \\
\hline & Very & A little & Neutral & A little & Very & \\
\hline pleasant & & & & & & unpleasant \\
\hline easy & & & & & & difficult \\
\hline interesting & & & & & & boring \\
\hline long & & & & & & short \\
\hline formal & & & & & & informal \\
\hline touching & & & & & & unmoving \\
\hline engaging & & & & & & undesirable \\
\hline clear & & & & & & confusing \\
\hline intense & & & & & & light \\
\hline informative & & & & & & uninformative \\
\hline stimulating & & & & & & tiresome \\
\hline
\end{tabular}

What word or passage has drawn your attention in the text?

Explain why you have chosen the word or the passage above. 

Do you like reading? ( ) Yes
( ) No
Why (not)?

If you could choose, what type of books or texts would you like to read at school? Place them in order (1 to 10) of preference, 1 being the one you would like to read the most, that is, your FIRST CHOICE, and 10 the one you would like to read the least:
( ) Novels
( ) News
( ) Magazine articles
( ) Fairy Tales
( ) Biography
( ) Graphic Novels
( ) Poetry
( ) Plays
( ) Traditional Literature
( ) Cartoons

\begin{abstract}
About you
Age:

Nationality:

Class:

Sex:

Boy

Girl
\end{abstract}

Study English since (age): 


\section{Appendix C \\ Open Questions - Answers}

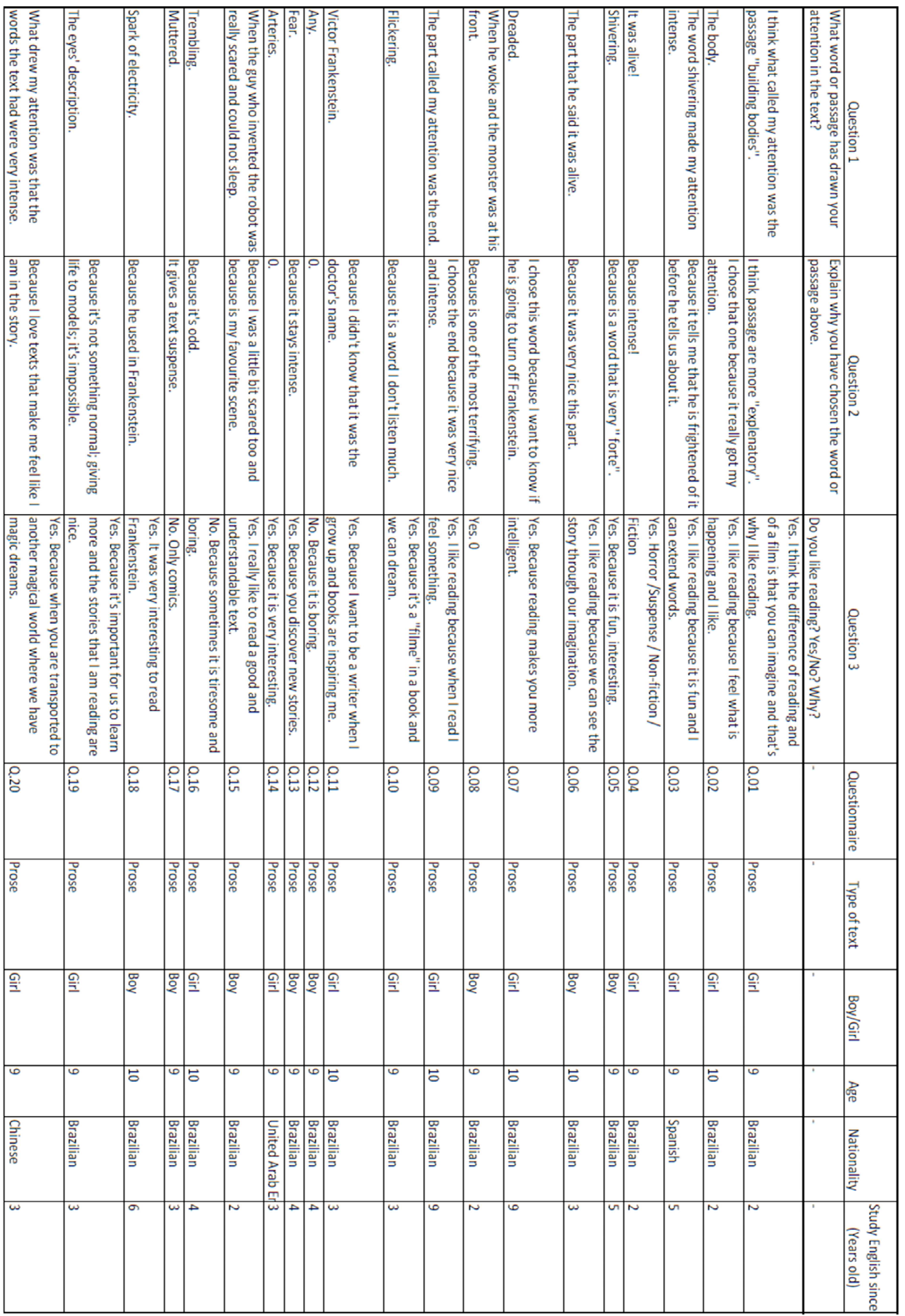




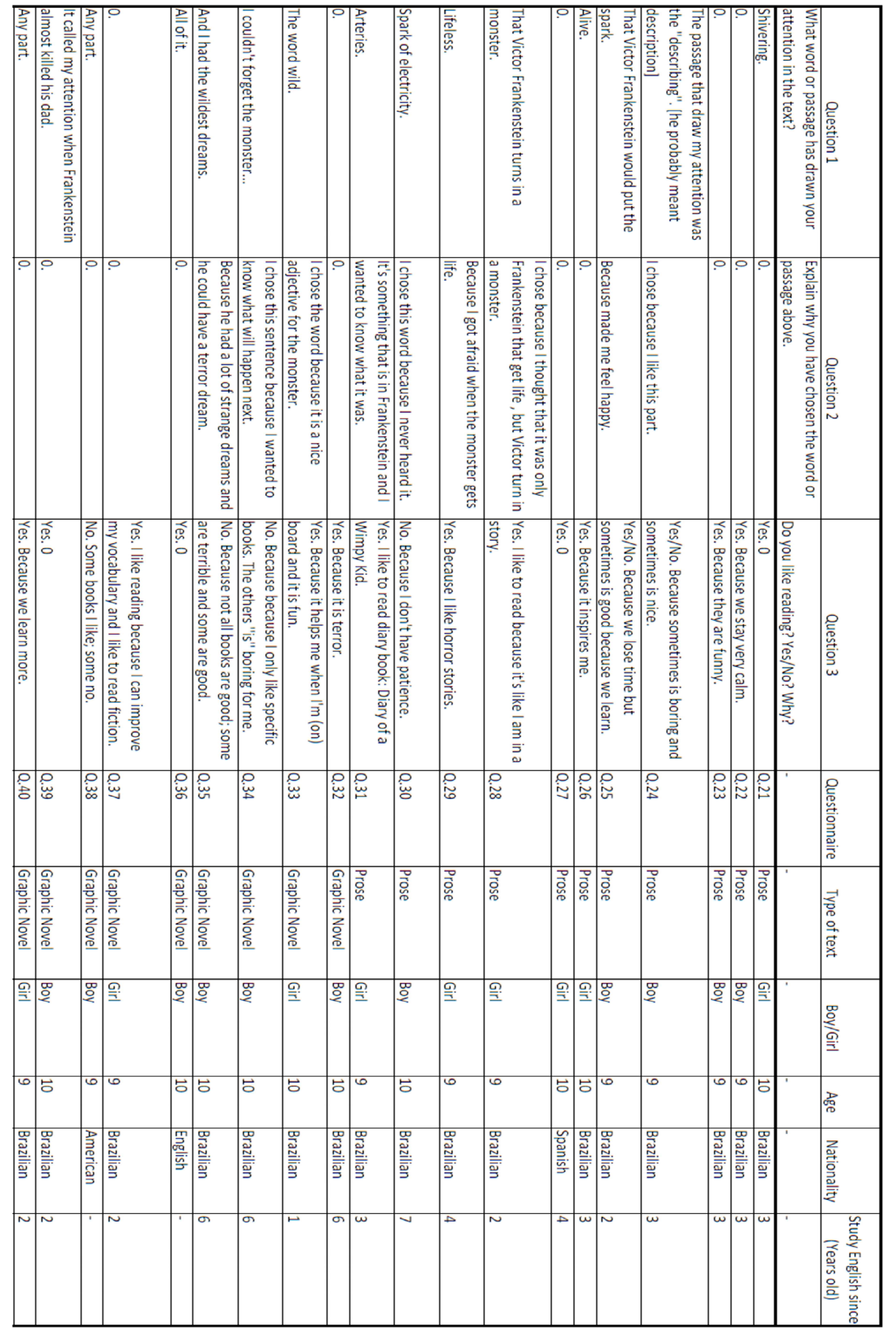




\begin{tabular}{|c|c|c|c|c|c|c|c|c|c|c|c|c|c|c|c|c|c|c|}
\hline 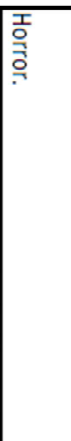 & 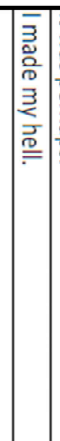 & 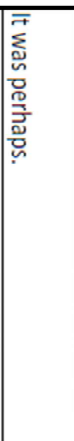 & 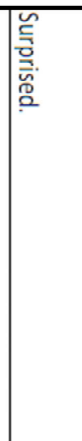 & 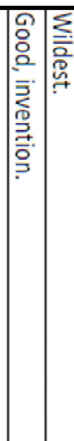 & 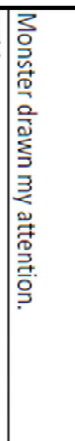 & 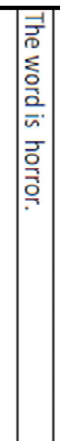 & & 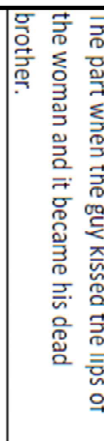 & & 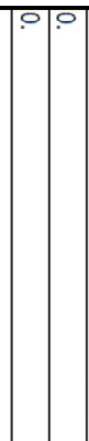 & $?$ & 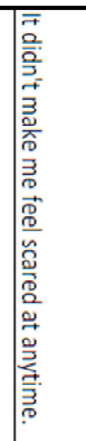 & 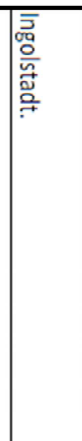 & 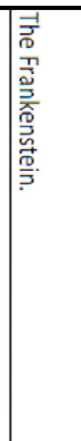 & 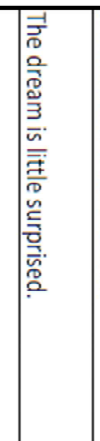 & 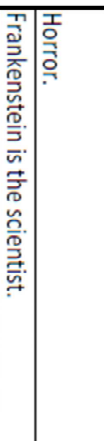 & 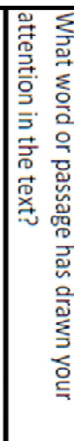 & \\
\hline 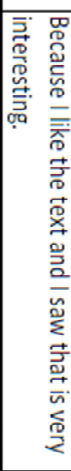 & 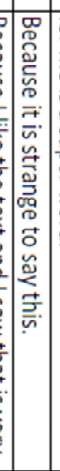 & 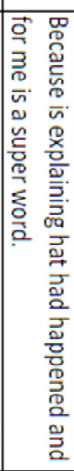 & 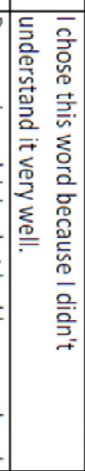 & 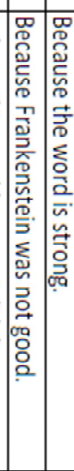 & 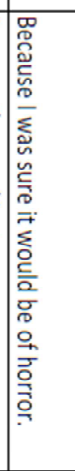 & 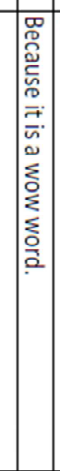 & 0 & 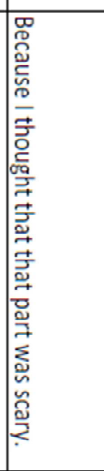 & 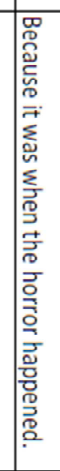 & 0 & 0 & ? & 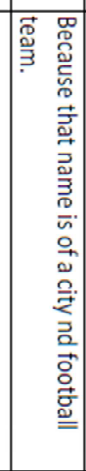 & 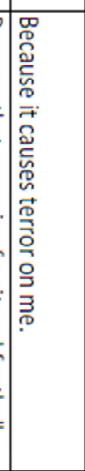 & 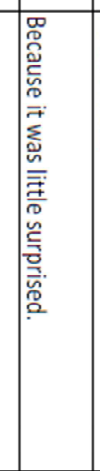 & 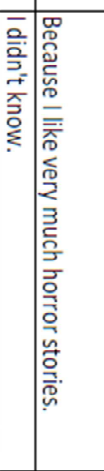 & 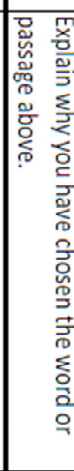 & 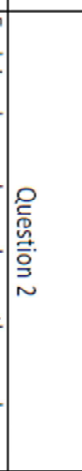 \\
\hline 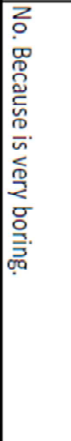 & 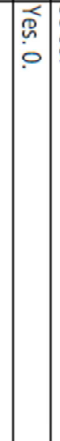 & $\begin{array}{l}\tilde{\alpha} \\
\vdots \\
0\end{array}$ & 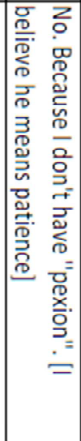 & 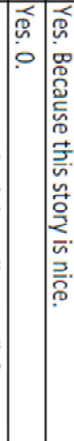 & 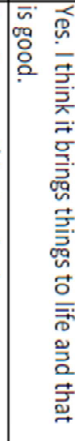 & 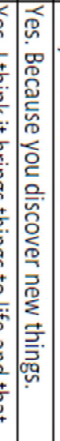 & 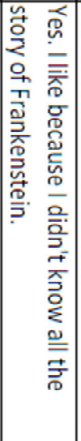 & 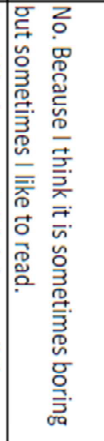 & $\because$ & 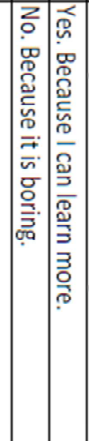 & 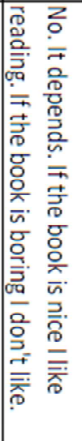 & 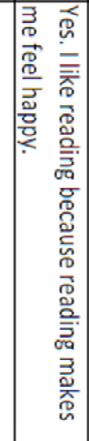 & 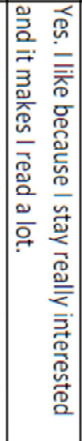 & 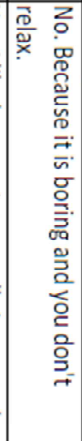 & 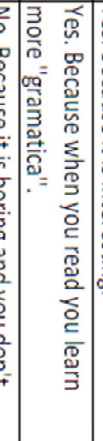 & 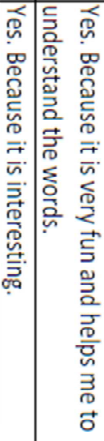 & 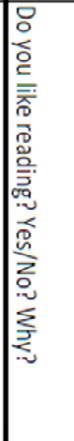 & $\mid$ \\
\hline 앙 & : & : & i & 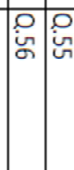 & P. & 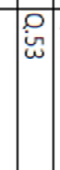 & 尊 & 说 & Pि & 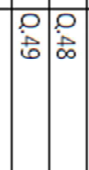 & $\stackrel{P}{\nexists}$ & Pि & 总 & P & $\stackrel{P}{\stackrel{P}{\omega}}$ & 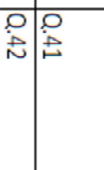 & & 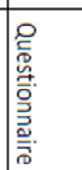 \\
\hline 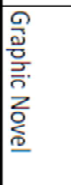 & 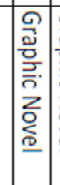 & 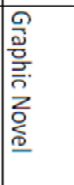 & 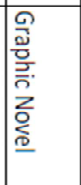 & 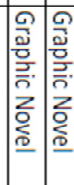 & 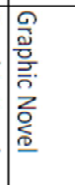 & 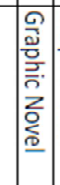 & 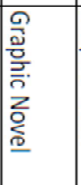 & 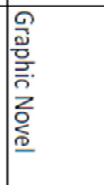 & 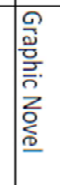 & 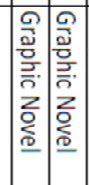 & 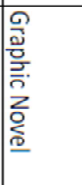 & 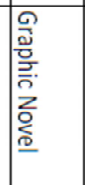 & 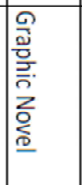 & 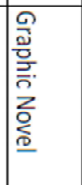 & 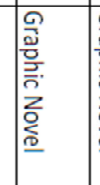 & 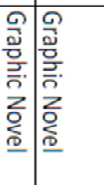 & & 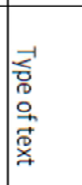 \\
\hline 韮 & פ & $\stackrel{\text { Q }}{\underline{\underline{P}}}$ & 类 & 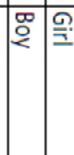 & 总 & 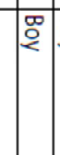 & 产 & 兽 & 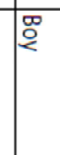 & 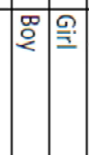 & 范 & ?로 & 兑 & $\underline{\underline{\underline{P}}}$ & $\stackrel{\rho}{\underline{\underline{P}}}$ & 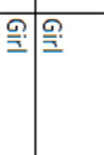 & & 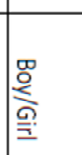 \\
\hline 6 & 0 & 6 & b & 50 & $\vec{o}$ & 0 & b & 它 & 6 & 00 & 6 & $\vec{\circ}$ & b & 0 & 6 & Б & & 㗊 \\
\hline 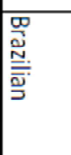 & 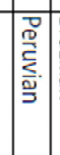 & 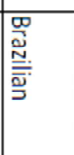 & 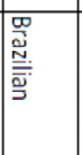 & 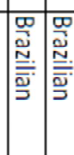 & 雲 & 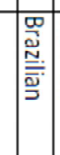 & 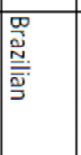 & 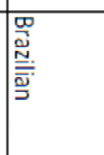 & 总 & 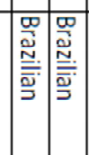 & 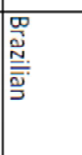 & 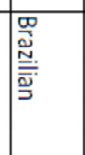 & 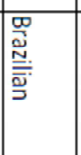 & 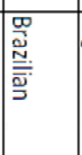 & 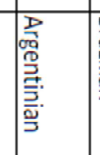 & 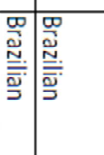 & & 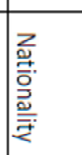 \\
\hline$N$ & $\omega$ & $A$ & ¿ & & P & $A$ & or & $\omega$ & $\omega$ & $\omega v$ & $\omega$ & N & $\omega$ & $\omega$ & $N$ & \begin{tabular}{l|l|l|}
$\Delta$ & $\infty$
\end{tabular} & & 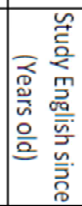 \\
\hline
\end{tabular}

